\title{
21. UPPER CRETACEOUS NANNOFOSSILS FROM LEG 120, KERGUELEN PLATEAU, SOUTHERN OCEAN ${ }^{1}$
}

\author{
David K. Watkins²
}

\begin{abstract}
Drilling on the Kerguelen Plateau during Leg 120 cored the most complete, best preserved record of the Late Cretaceous of the Southern Ocean to date. Two calcareous pelagic sedimentary sections (Sites 747 and 750 ) provide a record from the upper Turonian(?)-lower Coniacian through the Maestrichtian. Two major disconformities interrupt the record: upper Coniacian-lower Santonian and mid-Campanian. Site 748 contains a CampanianMaestrichtian record of neritic sedimentation dominated by nannofossil-bearing, intermittently silicified, glauconitic bioclastic grainstones to wackestones. Parts of the upper Maestrichtian and the mid-Campanian are absent at this site.

A set of 21 biostratigraphic events were used to correlate these sections. This combination of cosmopolitan and austral events allowed local, regional, and global correlation. Correlation of this scheme from the pelagic sites to the neritic site indicates the applicability of this system to the sparse, restricted assemblages of the upper Campanian and lower Maestrichtian. Comparison of the Kerguelen assemblages with previous records indicates weak provincialism and little endemism in the Coniacian through early Campanian Southern Ocean. Strong provincial distinction with high endemism is typical of the late Campanian through Maestrichtian. The change from weak to strong provincialism coincides with the mid-Campanian disconformity. The event marked or masked by this disconformity must have involved ecological decoupling of the Southern Ocean from more temperate surface-water masses. A new species, Zeugrhabdotus kerguelenensis, is named.
\end{abstract}

\section{INTRODUCTION}

Part of the mission of Ocean Drilling Program (ODP) Leg 120 was to investigate the early (Cretaceous) tectonic and paleoceanographic history of the central and southern Kerguelen Plateau (Fig. 1). This broad, 2300-km-long topographic high has a present-day average depth of 1-2 km. Evidence indicates that the plateau has never been in appreciably deeper water since the Early Cretaceous (Schlich, Wise, et al., 1989). This makes it an ideal locality to examine the calcareous record of a region of the Southern Ocean dominated by seafloor depths of $>4 \mathrm{~km}$.

Five holes drilled at three sites penetrated the Cretaceous. The nannofossil chalks from Sites 747 and 750 span the upper Turonian/lower Coniacian through Maestrichtian. The nannofossil sequence from these sites constitutes the most complete and best preserved record of the Late Cretaceous yet drilled in the Southern Ocean. Nannofossil-bearing glauconitic bioclastic grainstones to wackestones at Site 748 span the Campanian through lower Maestrichtian. The nannofossil biostratigraphy from this site provides the means to compare the CampanianMaestrichtian history of this unusual depositional site with other events on the Kerguelen Plateau and elsewhere.

The purpose of this report is (1) to subdivide the Upper Cretaceous at these sites biostratigraphically by using calcareous nannofossils to define a set of consistent, recognizable nannofossil events; and (2) to assess qualitatively the paleoecologic and paleobiogeographic affinities of the nannofossil assemblages. An explanation of the methodology used, the site descriptions, and a summary and comparison of the sites precede the discussion of austral nannofossil biostratigraphy and paleoecology and the conclusions.

\footnotetext{
${ }^{1}$ Wise, S. W., Jr., Schlich, R., et al., 1992. Proc. ODP, Sci. Results, 120: College Station, TX (Ocean Drilling Program).

2 Department of Geology, 330 Bessey Hall, University of Nebraska, Lincoln, NE 68588-0340, U.S.A
}

\section{METHODS}

The nannofossil biostratigraphy presented in this paper was largely drawn from an examination of the assemblages using the light microscope. Examination of some assemblages with a JEOL-T330 scanning electron microscope (SEM) was also necessary for solving taxonomic and/or biostratigraphic problems.

Nannofossil abundance and preservation varied widely in the Leg 120 material. Much of the Upper Cretaceous material from Site 748 contains sparse nannofossil assemblages diluted by other sediment. Concentrations of nannofossils by gravitational settling were used for most of this material. Material from Sites 747 and 750 , on the other hand, contains abundant to common nannofossils. Smear slides of raw sediment from these sites were used in determining nannofossil abundance (as a component of the sediment), nannofossil preservation, and the qualitative relative abundance of individual nannofossil taxa. Code letters expressing the abundance and preservation of these assemblages are based on the conventions that follow.

The abundance of nannofossils as a component of the sediment are as follows:

$$
\begin{aligned}
& A=>50 \% \text { of sediment by volume; } \\
& C=15 \%-50 \% \text { of sediment by volume; } \\
& F=1 \%-15 \% \text { of sediment by volume; and } \\
& R=<1 \% \text { of sediment by volume. }
\end{aligned}
$$

Relative abundances for individual nannofossil taxa are as follows:

$A=$ abundant $(1-10$ specimens per field of view at $\times 1500)$;

$\mathrm{C}=$ common ( 1 specimen per $2-10$ fields of view at $\times 1500$ );

$\mathrm{F}=$ few $(1$ specimen per $11-100$ fields of view at $\times 1500)$;

$R=$ rare $(1$ specimen per $101-1000$ fields of view at $\times 1500)$; and

$?=$ questionable presence of this species. 


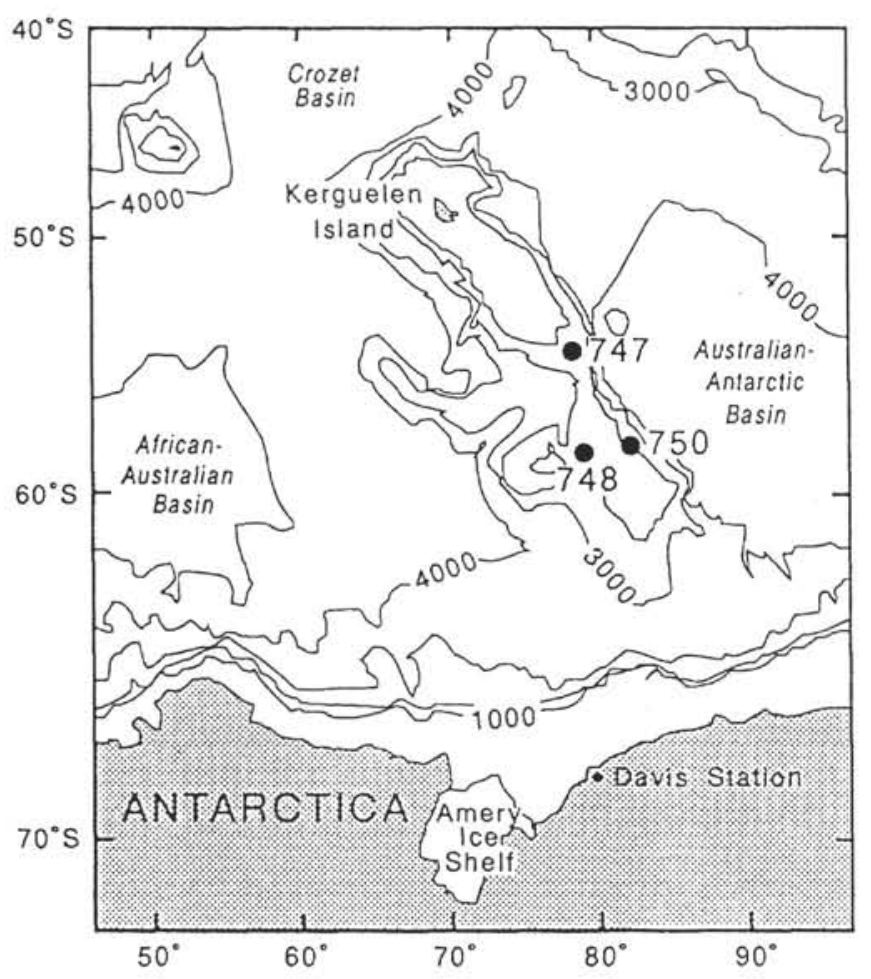

Figure 1. Location of Leg 120 sites.

An average state of preservation was assigned to each sample according to the following criteria:

$G=$ good, most specimens exhibit little or no secondary alteration;

$\mathrm{M}=$ moderate, specimens exhibit the effects of secondary alteration from etching and/or overgrowth (identification of species not impaired);

$\mathrm{P}=$ poor, specimens exhibit profound effects of secondary alteration from etching and/or overgrowth (identification of species impaired but possible in some cases).

Taxa included in this report are listed in the Appendix. Bibliographic references for these taxa are found in Loeblich and Tappan (1966, 1968, 1969, 1970a, 1970b, 1971, 1973), van Heck (1979a, 1979b, 1980a, 1980b, 1981a, 1981b, 1982a, 1982b, 1983), and Steinmetz (1984a, 1984b, 1985a, 1985b, $1986,1987 \mathrm{a}, 1987 \mathrm{~b}, 1988 \mathrm{a}, 1988 \mathrm{~b}, 1989)$. Any taxa not cited therein are cited in the references of this paper.

Age determinations and correlations of the Leg 120 nannofossil assemblages use a set of biostratigraphic event horizons developed in the course of this study (Fig. 2). Some of these have been used previously in cosmopolitan or austral zonations and can be used for global correlation; others have been recognized as useful in this study and may be applicable only for local or regional correlation. These are discussed in detail elsewhere in this paper (see "Austral Biostratigraphic Events" section, this chapter). The paleobiogeographic affinities and paleoecology of the assemblages were assessed by using the presence/absence or abundance of taxa that other studies have shown to have been sensitive to climate and conditions. These are discussed later in this paper (see "Paleoecology and Paleobiogeography of Austral Nannofossils" section, this chapter).

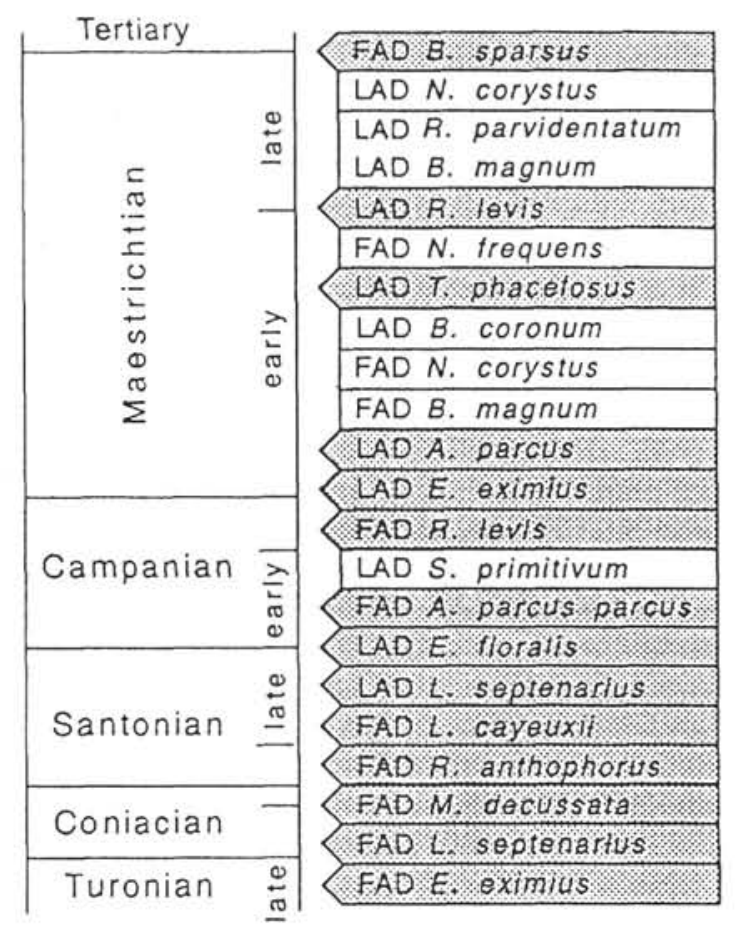

Figure 2. Biostratigraphic events used for age determination. Austral datums appear with white fields, cosmopolitan events are shaded for emphasis.

\section{SITE DESCRIPTIONS}

\section{Site 747}

Site 747 lies in the central portion $\left(54^{\circ} 48.68^{\prime} \mathrm{S}, 76^{\circ} 47.64^{\prime} \mathrm{E}\right)$ of the Kerguelen Plateau (Fig. 1) at a present-day water depth of $1695 \mathrm{~m}$. Two of the holes drilled at Site 747 (Holes 747A and $747 \mathrm{C}$ ) penetrated Cretaceous sediment. The Cretaceous in Hole $747 \mathrm{~A}$, recovered with the extended core barrel (XCB), penetrated $105.6 \mathrm{~m}$ of Cretaceous sediment for a recovery rate of approximately $75 \%$. The total depth of Hole $747 \mathrm{~A}$ was 256.0 $\mathrm{m}$ below seafloor (mbsf). Continuous coring in Hole $747 \mathrm{C}$, drilled with the rotary core barrel (RCB), began with Core $120-747 \mathrm{C}-6 \mathrm{R}$ at $252.0 \mathrm{mbsf}$ and continued through the sediment/basalt contact at $296.5 \mathrm{mbsf}$. Discounting the obvious downhole-caved gravels in Core $120-747 \mathrm{C}-10 \mathrm{R}$, recovery of this additional Cretaceous section was approximately $16 \%$. In total, these two holes penetrated a Cretaceous sedimentary section of about $101.0 \mathrm{~m}$ and produced a total recovery of approximately $56 \%$ (Fig. 3). The distribution of Cretaceous calcareous nannofossils at this site is given in Table 1 .

The sequence is topped by a volcaniclastic debris flow. Logging and biostratigraphic correlation indicates that this sequence begins in the Maestrichtian and continues into the lowermost Danian (Schlich, Wise, et al., 1989, p. 153). Below the debris-flow interval, the Cretaceous at Site 747 passes downward into a sequence of nannofossil chalk with intermittent chert. Cores 120-747A-21X through -23X (189.5-218.0 mbsf) contain common to abundant nannofossil assemblages having good to moderate preservation. The presence of Nephrolithus corystus and Reinhardtites levis in the absence of Tranolithus phacelosus and Biscutum coronum indicates that these sediments are mid-lower Maestrichtian (Fig. 3 and Table 1). Common $N$. corystus, Misceomarginatus pleniporus, and 

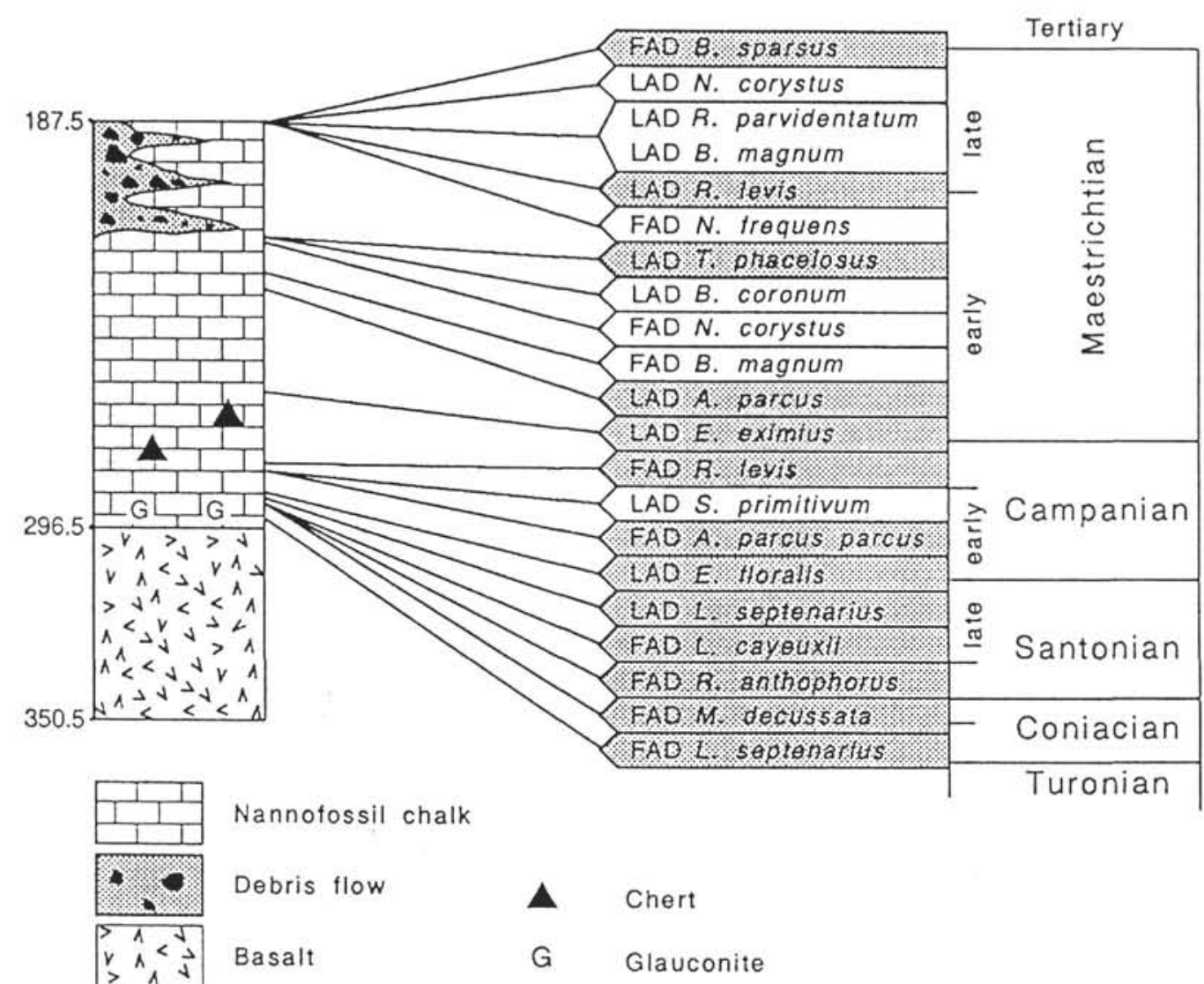

Figure 3. Placement of biostratigraphic events at Site 747.

Monomarginatus spp. indicate the strongly austral nature of these assemblages. Other common species in this interval include Acuturris scotus, Lucianorhabdus cayeuxii, Kamptnerius magnificus, Reinhardtites levis, and Repagalum parvidentatum. Watznaueria barnesae occurs only sporadically through this interval. The last appearance datum (LAD) of $B$. coronum and $T$. phacelosus and (probably) the first appearance datum (FAD) of $N$. corystus are all in Sample 120-747A$24 \mathrm{X}-1,114-115 \mathrm{~cm}$ (219.15 mbsf). This coincidence of range terminations may indicate truncation at a disconformity or may be an artifact of the sample spacing $(1.5 \mathrm{~m})$. Biscutum magnum has its first occurrence (FO) in Sample 120-747A24X-CC (227.2 mbsf). The LAD of Aspidolithus parcus is approximately $4 \mathrm{~m}$ below in Sample 120-747A-25X-3, 114-115 $\mathrm{cm}$ (231.65 mbsf).

Core recovery decreases downhole at this point because of the occurrence of chert in the sequence. The interval from Samples 120-747A-25X-3, 114-115 cm, to 120-747C-7R-1, 66-67 cm (231.65-262.12 mbsf), contains Aspidolithus parcus parcus without Eiffellithus eximius, indicating lower (but not lowest) Maestrichtian sediment. Biscutum coronum and $R$. parvidentatum are common throughout the interval, indicating its austral affinities. Conspicuously absent are such temperate indicators as Quadrum trifidum, Quadrum gothicum, and Quadrum sissinghii. However, Watznaueria barnesae is a consistent component of the assemblages in this interval, suggesting more moderate conditions compared with the overlying mid-Maestrichtian.

The Campanian/Maestrichtian boundary lies somewhere between the LAD of Eiffellithus eximius (Sample 120-747C-7R-1, $115-116 \mathrm{~cm} ; 262.65 \mathrm{mbsf})$ and the FAD of Reinhardtites levis
(Sample 120-747C-9R-2, 6-7 cm; 282.06 mbsf). The underlying section appears to be condensed and contains at least two significant disconformities. Sample 120-747C-9R-CC, 6-7 cm (289.90 mbsf), contains Aspidolithus parcus, Quadrum gothicum, $Q$. trifidum, and Reinhardtites sp. aff. $R$. anthophorus of Sissingh (1977) but lacks Reinhardtites levis, indicating an upper Campanian stratigraphic assignment equivalent to the nannofossil Subzones CC22a-CC22b (upper Campanian) of Perch-Nielsen $(1979 \mathrm{~b}, 1985)$. The presence of rare $Q$. gothicum and $Q$. trifidum in Sample 120-747C-9R-CC, 6-7 cm, and their absence in the overlying sequence indicate more moderate conditions and/or freer communication with temperate water masses to the north. The presence of common Seribiscutum primitivum and rare Biscutum dissimilis, however, indicates the dominantly austral affinities of this sample.

A change in lithology (evident in the core photographs; see Schlich, Wise, et al., 1989, p. 416) occurs at about 8-10 cm in Section 120-747C-9R-CC. The lower, darker lithology in this section (from about 8 to $18 \mathrm{~cm}$ ) contains a different assemblage from those above and below it. This assemblage, characterized by Sample 120-747C-9W-CC, 16-17 cm, contains Aspidolithus parcus expansus, Reinhardtites anthophorus, Lithastrinus grillii, and common Helicolithus trabeculatus, but it lacks Aspidolithus parcus parcus, Reinhardtites sp. aff. R. anthophorus, and Eprolithus floralis. The lack of $A$. parcus parcus and the high abundance of $H$. trabeculatus indicate a lowest Campanian placement for this sample. Thus, a significant disconformity (with an hiatus of at least 5 m.y.) exists between Samples 120-747C-9R-CC, 6-7 and 16-17 cm.

Samples 120-747C-10R-1, 10-11 and 40-41 cm (290.1 and 290.4 mbsf, respectively) contain Aspidolithus parcus expan- 
Table 1. Calcareous nannofossil distribution in the Upper Cretaceous of Site 747.

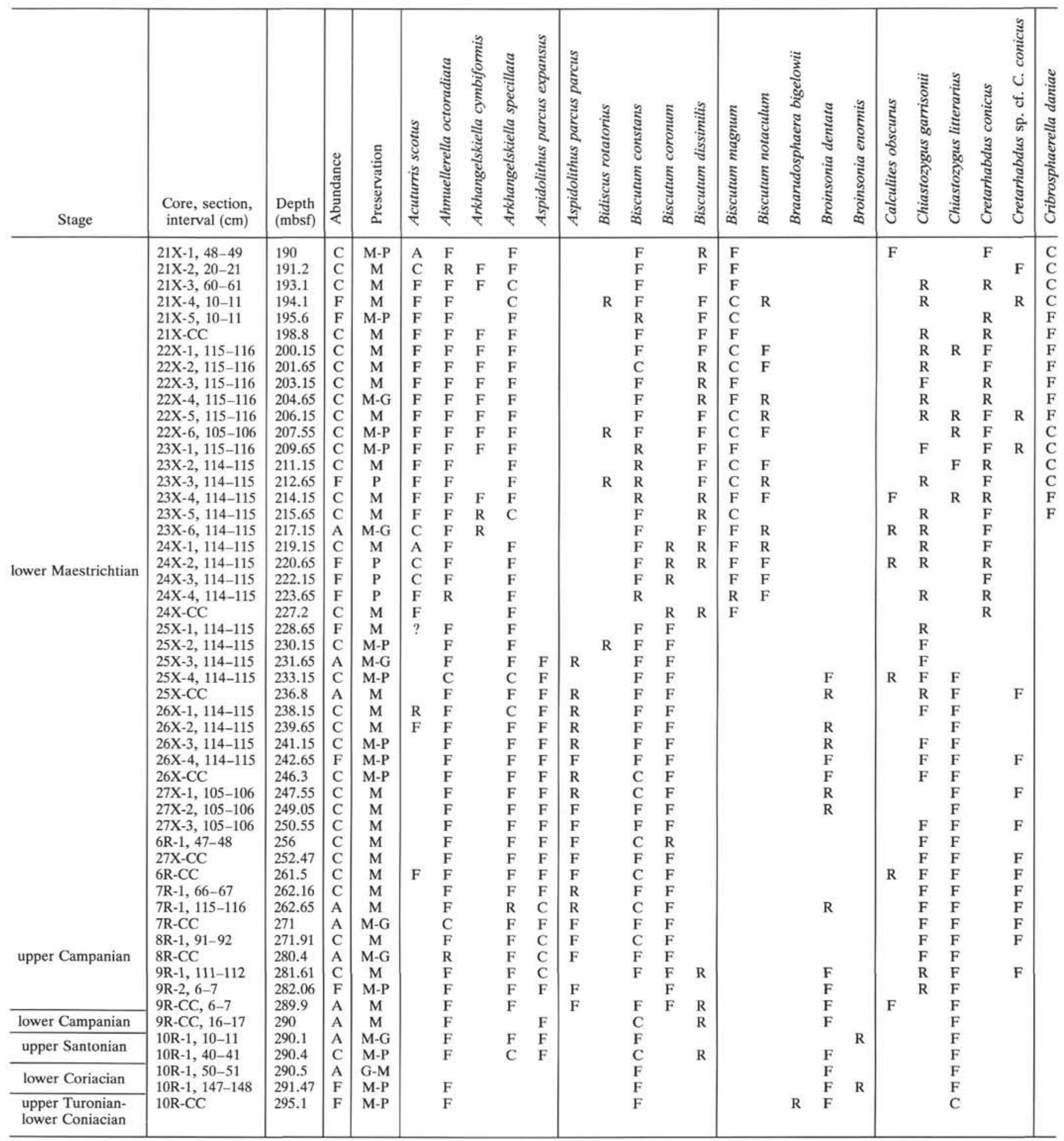

sus, Eprolithus floralis, Lucianorhabdus cayeuxii, Micula decussata, and Reinhardtites anthophorus, indicating a late Santonian age (equivalent to Zone CC16 of Perch-Nielsen $1979 b, 1985)$. The presence of many $S$. primitivum in these samples indicate the austral affinities of the assemblages.

A second significant disconformity separates the upper Santonian chalk from the underlying interval. Samples 120 747C-10R-1, 50-51 and 147-148 cm (290.4 and $291.47 \mathrm{mbsf}$, respectively) contain Lithastrinus septenarius and Thiersteinia ecclesiastica but lack Aspidolithus parcus expansus, Lucianorhabdus cayeuxii, Micula decussata, and Reinhardtites anthophorus. This indicates nannofossil Subzone $\mathrm{CC} 13 \mathrm{~b}$ (lower Coniacian). The presence of Thiersteinia ecclesiastica suggests austral affinities for these assemblages. Section 120-747C-10R-CC contains fragments of glauconitic bioclastic packstones composed of foraminifers 


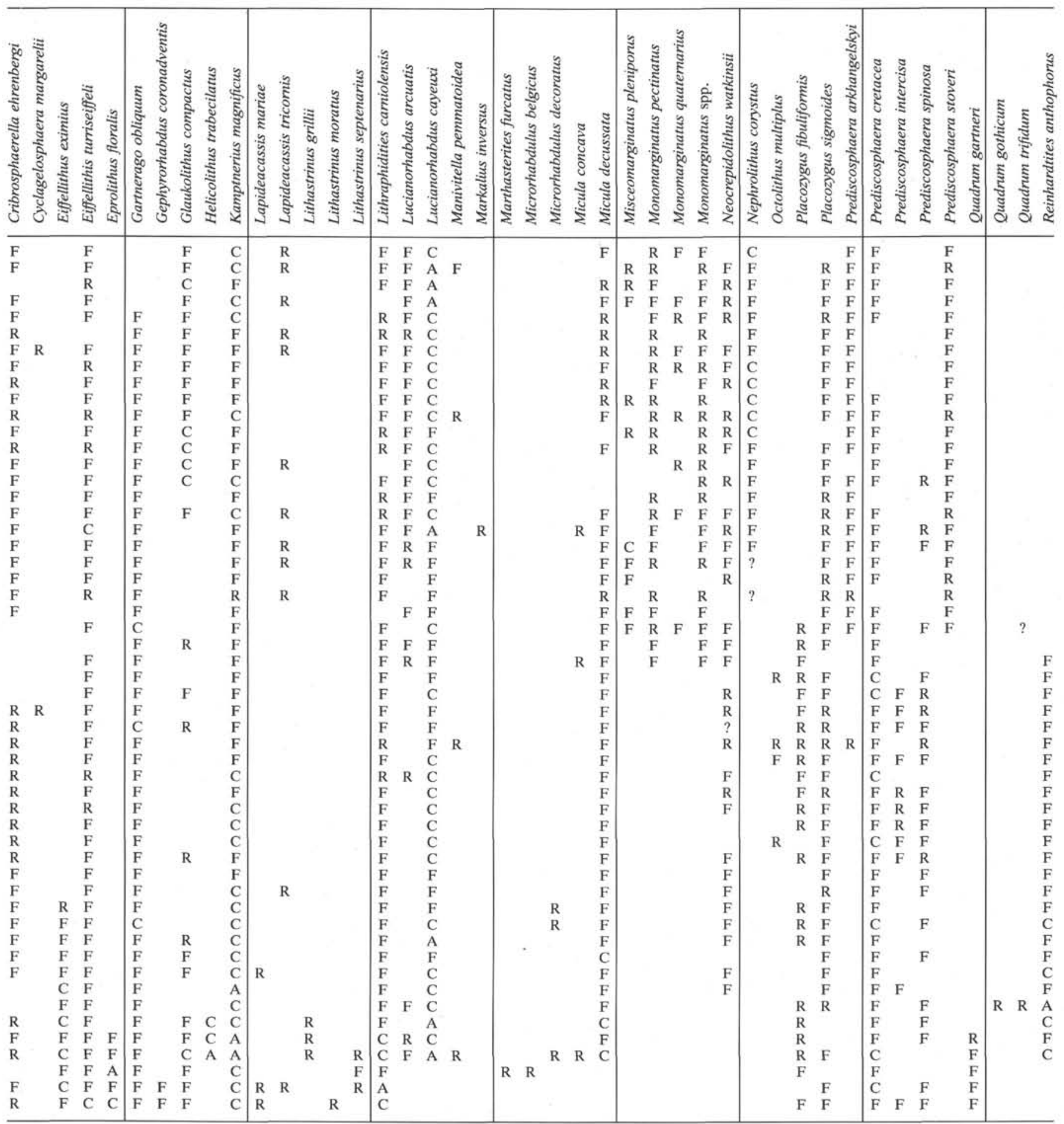

and inoceramid debris with a matrix of nannofossils and fine-grained carbonate. Nannofossil assemblages in these fragments are similar to those in the lower part of Section 120-747C-10R-1 but lack $L$. septenarius. This indicates the upper Turonian to lower Coniacian Subzones CC12-CC13a. The poor core recovery in Core $120-747 \mathrm{C}-10 \mathrm{R}$ makes it impossible to determine whether this biostratigraphic and lithologic change is abrupt (= disconformity) or gradational. The contact between the sedimentary section and the underlying basalt was not recovered.

\section{Site 748}

Site 748 is located in the western part of the Raggatt Basin $\left(58^{\circ} 26.45^{\prime} \mathrm{S}, 78^{\circ} 58.89^{\prime} \mathrm{E}\right)$ on the Southern Plateau at a water depth of approximately $1291 \mathrm{~m}$. Hole $748 \mathrm{C}$ (cored by RCB) penetrated a thick (approximately $409 \mathrm{~m}$ ) sequence of Cretaceous sediment overlying highly altered phyric basalt. Only the upper portion (Cores 120-748C-27R through 120-748C58R; approximately $285 \mathrm{~m}$ ) of this sequence contains calcareous nannofossils. Core recovery in this fossiliferous interval 
Table 1 (continued).

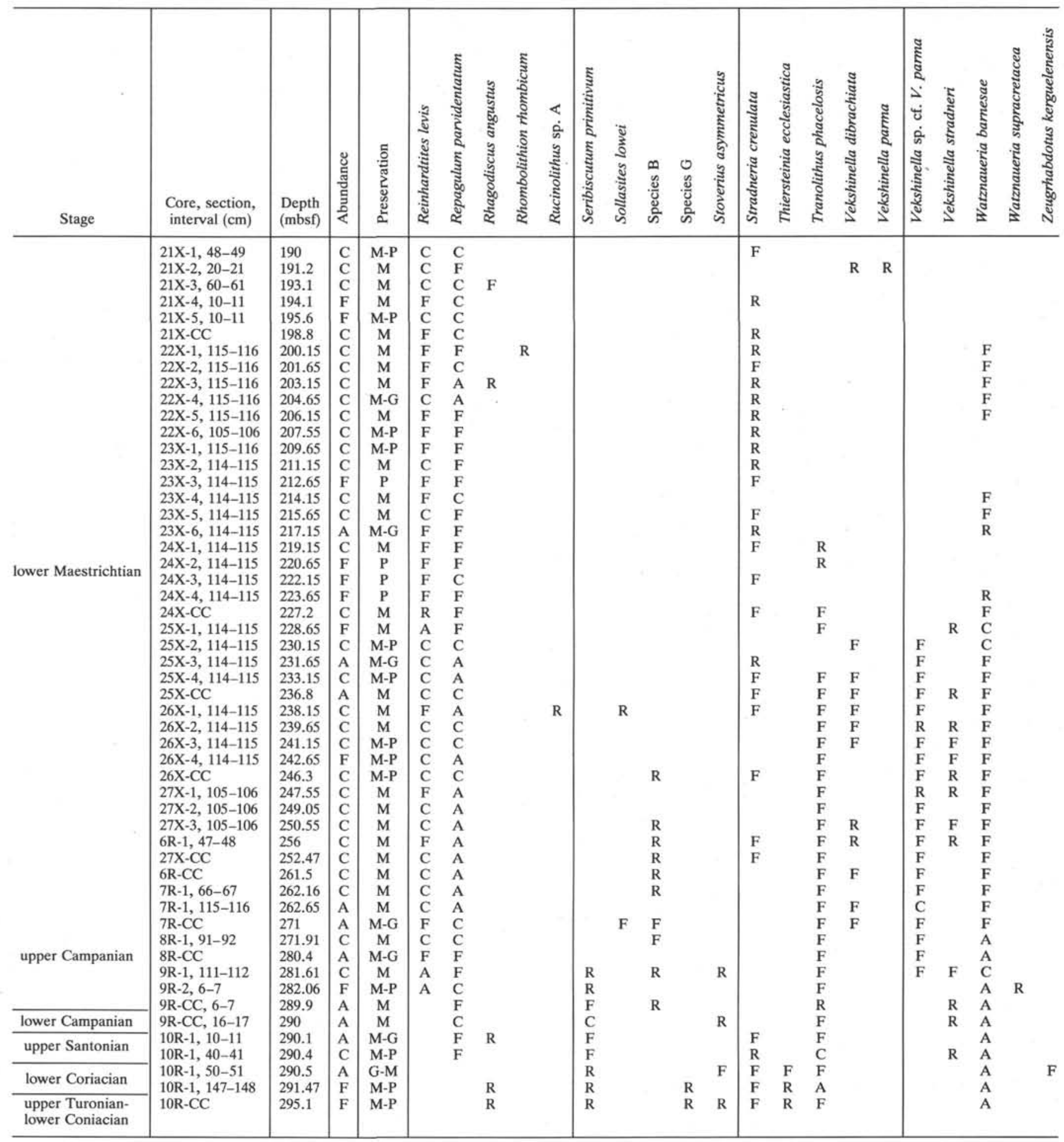

Note: Abundances assessed from smear slides.

was approximately $21 \%$. This interval consists largely of glauconitic bioclastic packstones, wackestones, and grainstones. Grain size varies from fine to coarse; some intervals have very coarse glauconitic grainstones containing shallowwater macrofossil fragments including bryozoans, inoceramids, foraminifers, molluscs, crinoids, and (rare) coralline red algae. Secondary silicification occurs sporadically throughout the sequence. Nannofossils are always a secondary compo- nent in this sequence and are totally absent in some intervals. With few exceptions, gravitational settling was necessary to concentrate the nannofossils sufficiently for study. The relative abundances given for taxa in Table 2 reflect those from gravitationally concentrated samples. Preservation varies greatly because of the wide range of diagenetic overprints within the sequence. In fine-grained sediments that have not undergone secondary silicification, nannofossil preservation is 
generally moderate to good, and some samples exhibit excellent preservation.

Four distinct biostratigraphic intervals can be recognized in Core 120-748C-27R (Fig. 4). Sample 120-748C-27R-1, 68-69 cm (407.68 mbsf), contains moderate to poorly preserved assemblages that include Nephrolithus frequens, $N$. corystus, and Repagalum parvidentatum, but lack Biscutum magnum and Reinhardtites levis. This association indicates a mid-upper Maestrichtian assignment for this interval. The abundance of these species as well as Cribrosphaerella daniae and the lack of any temperate taxa indicate the strongly austral affinities of these assemblages. Sample 120-748C-27R-1, 90-91 cm (407.9 mbsf), contains a similar assemblage with the addition of $B$. magnum, indicating a slightly older age for this sediment. The next lower sample (120-748C-27R-1, 147-148 cm; 408.47 mbsf) includes both $R$. levis and $N$. frequens, indicating a slightly lower assignment of lowest upper Maestrichtian for this sample. The remainder of this core (Sample 120-748C-27R-2, 16-18 cm, through Section $120-748 C-27 R-C C$; $408.66-416.3$ mbsf) is characterized by nannofossil assemblages that contain $N$. corystus and $R$. levis but lack $N$. frequens, Biscutum coronum, and Tranolithus phacelosus. This assemblage indicates an upper lower Maestrichtian assignment for the interval. Associated species indicate austral affinities.

Samples from Core $120-748 \mathrm{C}-28 \mathrm{R}$ are biostratigraphically distinct from those both above and below the core. The co-occurrence of Nephrolithus corystus, Tranolithus phacelosus, and Biscutum coronum indicates a mid-lower Maestrichtian placement of this sediment. Unfortunately, only about 1 $\mathrm{m}$ of sediment was recovered in this core. As a result, the boundaries between the biostratigraphic unit in this core and of those above and below it were not be observed.

The interval from Core $120-748 \mathrm{C}-29 \mathrm{R}$ through Sample $120-748 \mathrm{C}-40 \mathrm{R}-1,17-18 \mathrm{~cm}(426.4-530.67 \mathrm{mbsf})$, is characterized by intermittently silicified glauconitic grainstones and rudstones. The presence of fossils including bryozoans, inoceramids, echinoids, crinoids, and coralline red algae indicate a shallow (inner shelf) depositional environment (Schlich, Wise, et al., 1989). Calcareous nannofossils are present only in those sediments that are fine grained and unsilicified. Even when present, nannofossils are always a minor component in the sediments of this interval. Most of the samples examined from this interval are barren; these were not reported in Table 2. Despite the apparently adverse conditions for nannofossil preservation in this interval, some of the samples (such as Sample 120-748C-30R-CC) exhibit surprisingly well-preserved assemblages. All the assemblages within this interval are characterized by the absence of both Nephrolithus corystus and Aspidolithus parcus, indicating the middle part of the lower Maestrichtian. The FAD of Biscutum magnum is in Sample 120-748C-32R-CC. This FAD may be higher than it should be because all the samples examined from Cores 120-748C-33R and -34R except Sample 120-748C-34R-CC are barren of nannofossils. This uncertainty is indicated by the error box in Figure 4. The assemblages are dominated by Repagalum parvidentatum and Kamptnerius magnificus, indicating their austral affinity.

Sample 120-748C-40R-1, 57-58 cm (531.07 mbsf), contains the LAD of Aspidolithus parcus parcus, placing it in the lower part of the lower Maestrichtian. This sample is underlain by a three cores (120-748C-41R through -43R; 540.0-568.5 mbsf) containing silicified bioclastic grainstones and packstones from which no nannofossils could be recovered. The sedimentary rock recovered in Cores $120-748 \mathrm{C}-44 \mathrm{R}$ through Sample $120-748 \mathrm{C}-49 \mathrm{R}-1,14-16 \mathrm{~cm}(568.5-616.14 \mathrm{mbsf})$, is only inter- mittently silicified, and nannofossils are remain preserved in some finer grained intervals. These assemblages are biostratigraphically similar to those in Sample 120-748C-40R-1, 57-58 cm.

Sample 120-748C-49R-CC through Core 120-748C-52R (625.5-654.0 mbsf) contains rare, moderately preserved nannofossil assemblages, which include both Eiffellithus eximius and Reinhardtites levis, indicating that the Campanian/Maestrichtian boundary probably occurs within this interval. Rare specimens of Seribiscutum primitivum were observed in Samples 120-748C-50R-CC through-51R-CC (Table 2).

The FAD of Reinhardtites levis occurs in Sample 120-748C$52 \mathrm{R}-\mathrm{CC}$ (654.0 mbsf). The underlying sequence from Cores $120-748 \mathrm{C}-53 \mathrm{R}$ through $-58 \mathrm{R}$ contain rare, moderately to poorly preserved nannofossil assemblages that include Aspidolithus parcus parcus and A. parcus expansus. The occurrence of these two forms in the absence of $R$. levis and Eprolithus floralis indicates the mid to lower Campanian. No direct evidence is available to refine the stratigraphic placement of this interval more closely. Because of the almost total paleoecologic exclusion of such temperate forms as Ceratolithoides aculeus, Quadrum gothicum, and Quadrum trifidum from the Campanian of the Austral Realm, their absence from this interval is not age diagnostic. The assemblages in Samples 120-748C-55R-CC, $-56 \mathrm{R}-2,7-9 \mathrm{~cm}$, and $-58 \mathrm{R}-\mathrm{CC}(682.5,684.07$, and $711.0 \mathrm{mbsf}$, respectively), however, contain some indirect evidence that suggests they are lowest Campanian. Helicolithus trabeculatus is a major component of all three of these assemblages. Although this species is not restricted to this stratigraphic level (e.g., it occurs as rare specimens in lower Maestrichtian Sample 120748C-36R-1, 115-116 cm; Table 2), it has been found to be a major assemblage component of Austral Campanian sections only near the Santonian/Campanian boundary (see discussion in "Biostratigraphic Events" section, this chapter).

A fragment of sediment in Section 120-748C-60R-CC contains a similar assemblage to that described in the preceding text. The poor core recovery in Cores $120-748 \mathrm{C}-59 \mathrm{R}$ and $-60 \mathrm{R}$ $(>1 \%)$, however, suggests that this material may be cavings from above. The rest of the underlying sedimentary section (Core 120-748C-62R through Sample 120-748C-79R-4, $60 \mathrm{~cm}$; $727.5-896.1 \mathrm{mbsf}$ ) is barren of calcareous nannofossils. It has been dated by palynomorphs as upper Cenomanian to Coniacian (Mohr and Gee, this volume).

\section{Site $\mathbf{7 5 0}$}

Site 750 is in the eastern part of the Raggatt Basin on the Southern Kerguelen Plateau (Fig. 1) in approximately $2031 \mathrm{~m}$ water depth. Both Holes $750 \mathrm{~A}\left(57^{\circ} 35.54^{\prime} \mathrm{S}, 81^{\circ} 14.42^{\prime} \mathrm{E}\right)$ and $750 \mathrm{~B}$ $\left(57^{\circ} 35.52^{\prime} \mathrm{S}, 81^{\circ} 14.37^{\prime} \mathrm{E}\right)$ penetrated Cretaceous sediment; together, they form a 325 -m-thick composite Cretaceous sedimentary section (Fig. 5). The upper $273.5 \mathrm{~m}$ of this sequence consists of nannofossil chalks of late Turonian-early Coniacian to latest Maestrichtian age. The lower $51.5 \mathrm{~m}$ of sediment consists of silty claystone with charcoal, siderite, and minor conglomerates that are barren of calcareous nannofossils. Palynomorph data suggests an early Albian age for this interval (Mohr and Gee, this volume). Core recovery in the Upper Cretaceous chalk sequence (Sample 120-750A-15R-3, $91 \mathrm{~cm}$, through Core 120-750B-11R; $350.0-623.5 \mathrm{mbsf}$ ) was only $14.2 \%$. This is a result, in part, of the unusual discontinuous coring program in the lower portion of the sequence that was necessitated by time restraints (see Schlich, Wise, et al., 1989, p. 277). Specifically, Hole 750 A was continuously cored, whereas coring of the Upper Cretaceous occurred only at $10-30-\mathrm{m}$ intervals in Hole $750 \mathrm{~B}$. Despite this poor recovery, a coherent sequence of biostratigraphic events can be 
Table 2. Calcareous nannofossil distribution in the Upper Cretaceous of Site 748.

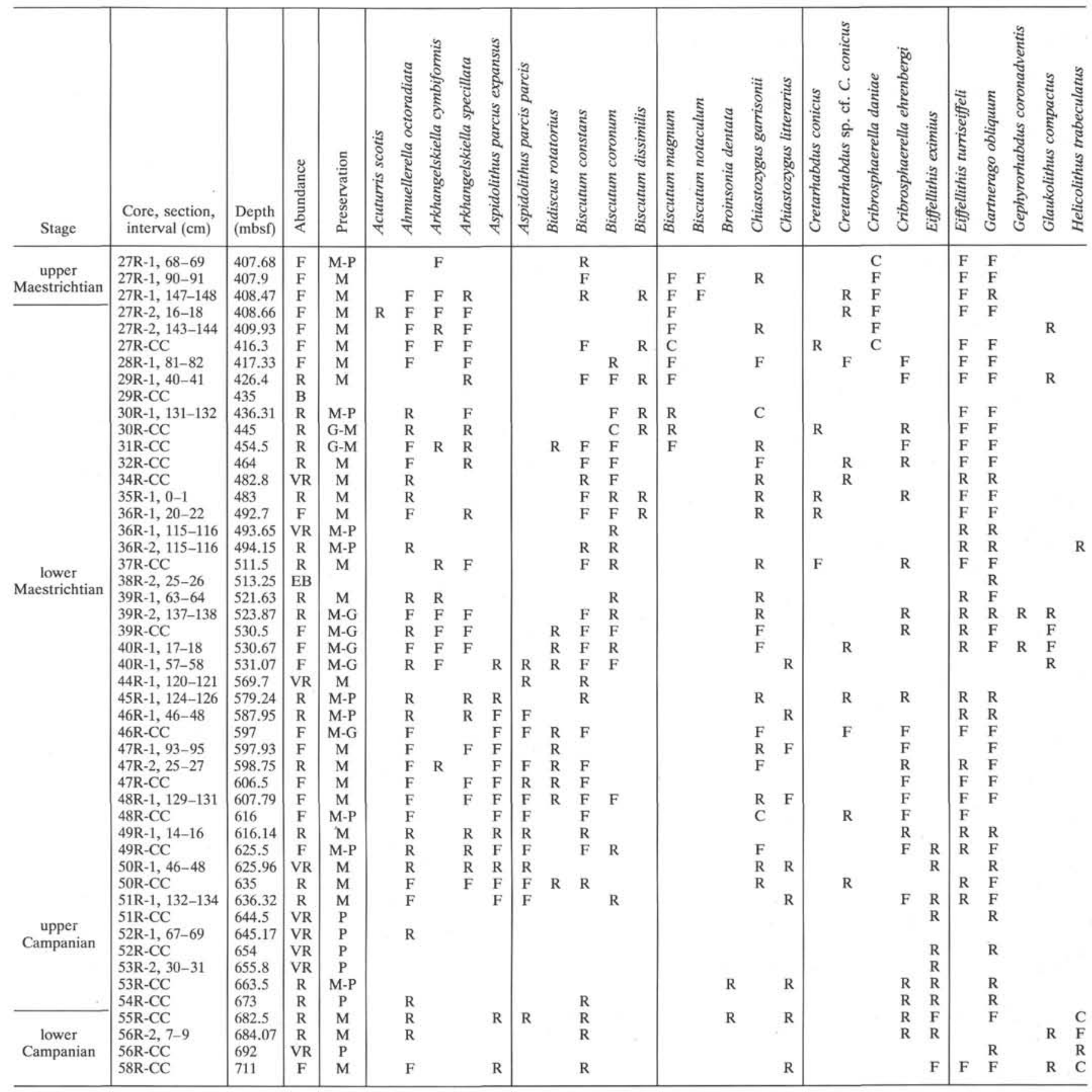

recognized that places the section in a fairly detailed framework. The distribution and abundance of nannofossil taxa in this sequence is given in Table 3.

The upper Maestrichtian is a 38.8-m-thick nannofossil chalk sequence that is composed of purely austral assemblages. The interval from Samples 120-750A-15R-3, 90-91 $\mathrm{cm}$, through $-19 \mathrm{R}-2,20-21 \mathrm{~cm}(350.0-386.4 \mathrm{mbsf})$, contains Nephrolithus frequens without $N$. corystus, indicating a latest Maestrichtian age. The very high abundance of Prediscosphaera stoveri in the uppermost samples suggests that the top of the sequence truncates at the Cretaceous/Tertiary bound- ary (following the work of Pospichal, 1989). The abundance of Cribrosphaerella daniae and the absence of temperate forms indicate the austral nature of these assemblages. Nephrolithus corystus has its LAD in Sample 120-750A-19R-2, 114-115 cm (387.35 mbsf), indicating the lower upper Maestrichtian. The underlying sample (120-750A-19R-3, 110-112 cm; $388.8 \mathrm{mbsf})$, contains the LAD of Biscutum magnum and Repagalum parvidentatum. The abundance of the latter species, in combination with the presence of $N$. corystus, B. magnum, and Misceomarginatus pleniporus, indicates the austral affinities of these assemblages. 


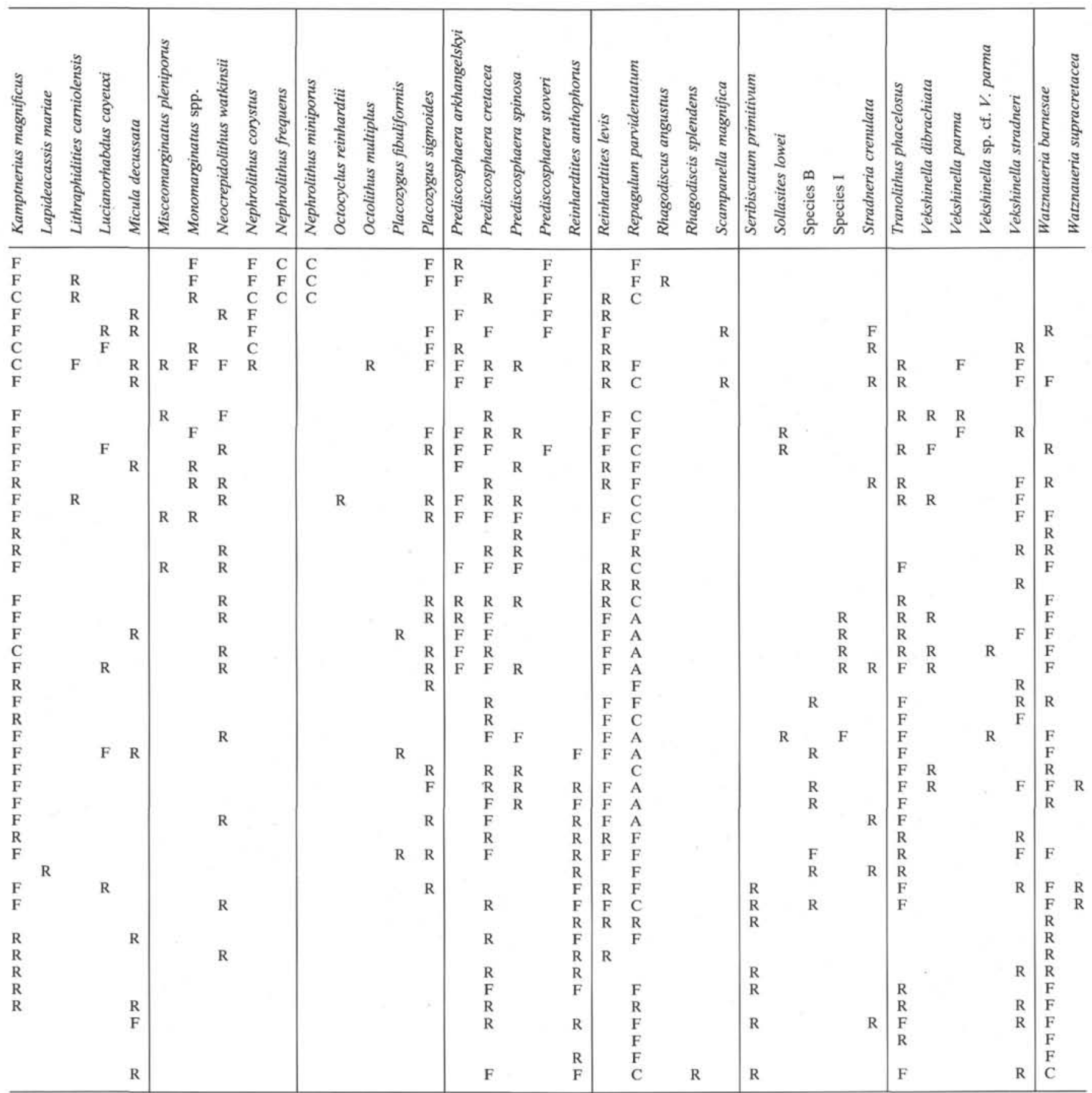

Note: Abundances assessed from gravitationally concentrated samples: they are comparable to other sites only in relative differences in abundance between taxa.

The interval from Samples 120-750A-20R-1, 20-21 cm, through -20R-5, 20-21 cm (394.6-400.6 mbsf), contains both Nephrolithus frequens and Reinhardtites levis, indicating the upper lower Maestrichtian. Samples 120-750A-20R-CC and -21R-1, 32-33 cm (404.0-404.32 mbsf), contain neither $N$. frequens nor Tranolithus phacelosus. The latter species has its LAD in Sample 120-750A-21R-1, 114-115 cm. The interval from this sample through the remainder of Core $120-750 \mathrm{~A}-21 \mathrm{R}$ contains assemblages with $T$. phacelosus but without Biscutum coronum. Tranolithus phacelosus, B. coronum, and Nephrolithus corystus occur together throughout Cores $120-750 \mathrm{~A}-22 \mathrm{R}$ and -23R (413.6-442.6 mbsf). The interval from Cores $120-750 \mathrm{~A}$ 24R through 120-750B-5R (442.6-488.9 mbsf) contains assemblages with Biscutum magnum and B. coronum but without $N$. corystus and Aspidolithus parcus. This association indicates a lower lower Maestrichtian placement for this interval. Watznaueria barnesae is absent from all but two samples, in which it occurs as very rare specimens. The affinities of these samples appear to be solely austral.

The coring program changed from continuous coring in Hole $750 \mathrm{~A}$ to a "wash and core" program in Hole $750 \mathrm{~B}$. Sample depths (in mbsf) are reported for horizons in these 

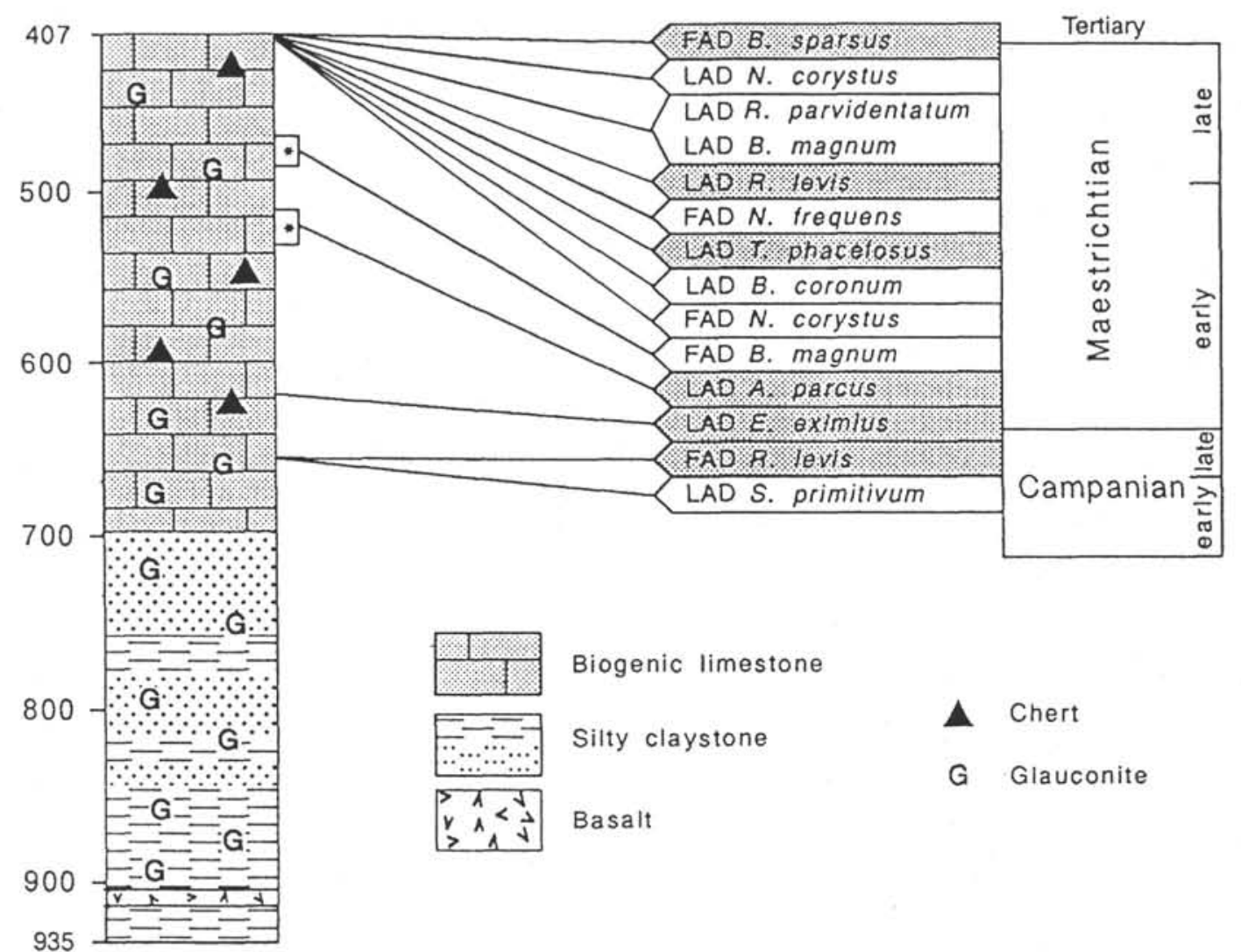

Biogenic limestone
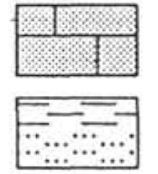

Silty claystone

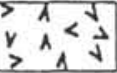

Basalt

Figure 4. Placement of biostratigraphic events at Site 748. Boxes containing asterisks on the placement of FAD of Biscutum magnum and LAD of Aspidolithus parcus indicate the stratigraphic uncertainty due to barren intervals of glauconitic bioclastic grainstone.

cores in accordance with ODP protocol; however, the reader should keep in mind that intervals between cores may be as large as $20 \mathrm{~m}$. Thus, for example, the FAD of Reinhardtites levis (which occurs between the base of Core 120-750B-7W and the top of Core $120-750 \mathrm{~B}-8 \mathrm{~W}$ ) could actually be anywhere within $510.5-544.7 \mathrm{mbsf}$. A reflection of this is indicated by the error boxes in Figure 5.

Sample $120-750 \mathrm{~B}-6 \mathrm{~W}-1,0-1 \mathrm{~cm}(488.5 \mathrm{mbsf})$, contains assemblages that lack Biscutum magnum and Aspidolithus parcus, indicating a lower (but not lowest) lower Maestrichtian placement. Aspidolithus parcus, but not Eiffellithus eximius, is present in the underlying interval from Samples 120-750B-6W-1, 90-91 cm, through -7W-1, 0-1 cm (489.4-507.9 mbsf), indicating a lower Maestrichtian interval equivalent to nannofossil Subzone CC23a of Perch-Nielsen (1985). In the remainder of this core (Sample 120-750B-7W-1, 45-47 cm, through Section 120-750B7W-CC; 508.35-527.3 mbsf), A. parcus, Reinhardtites levis, and $E$. eximius all occur together. This indicates an interval straddling the Campanian/Maestrichtian boundary (equivalent to Subzone CC22c of Perch-Nielsen, 1985).

The underlying sequence is separated from the strata above by a disconformity that encompasses most of the lower upper Campanian and upper lower Campanian. Core 120-750B-8W through Sample 120-750B-10W-1, 36-38 cm (527.3-566.36 mbsf), contain Seribiscutum primitivum, Aspidolithus parcus parcus, and Reinhardtites anthophorus but lack $R$. levis and Eprolithus floralis, indicating the lower Campanian. The exact placement of this interval within the lower Campanian is difficult to ascertain other than that it lies above the FAD of $A$. parcus parcus. Abundant to common specimens of Helicolithus trabeculatus occur throughout Core 120-750B-10W.

Samples $120-750 \mathrm{~B}-10 \mathrm{~W}-1,48-50$ and $80-81 \mathrm{~cm}$ (566.5 and 566.8 mbsf, respectively), contain assemblages with Eprolithus floralis and Lucianorhabdus cayeuxii but without Lithastrinus septenarius. This is indicative of an upper Santonian interval equivalent to the Lucianorhabdus cayeuxii nannofossil Zone of Sissingh (1977; equivalent to Zone CC16 of Perch-Nielsen, 1985). The underlying sample (120-750B10W-1, 114-115 cm; 567.15 mbsf) contains Micula decussata, L. septenarius, and Reinhardtites anthophorus but lacks $L$. cayeuxii, indicating the lower Santonian (equivalent to Zone CC15 of Perch-Nielsen, 1985).

Core $120-750 \mathrm{~B}-11 \mathrm{~W}$ can be divided into two biostratigraphic units based on the distribution of Lithastrinus septenarius. The upper part of the core (Section 120-750B-11W-1 through Sample 120-750B-11W-2, 6-8 cm; 594.6-596.16 mbsf) contains L. septenarius but lacks Reinhardtites anthophorus and Micula decussata, indicating the lower Coniacian (equivalent to Subzone CC13a of Perch-Nielsen, 1985). The lower part of the core (Sample 120-750B-11W-2, 76-77 cm, through Section 120-750B$11 \mathrm{~W}-\mathrm{CC} ; 597.38-623.5 \mathrm{mbsf}$ ) lacks $L$. septenarius. The presence of Eiffellithus eximius in the absence of L. septenarius indicates an upper Turonian to lower Coniacian assignment equivalent to nannofossil Zone CC12 to Subzone CC13a of Perch-Nielsen (1985). The presence or absence of Marthasterites furcatus is used to separate Zones $\mathrm{CC} 12$ from $\mathrm{CC} 13$ in temperate regions. However, it is not possible to use this criterion in the carbonaterich sections of the Kerguelen Plateau because $M$. furcatus is not consistently present at this location. 


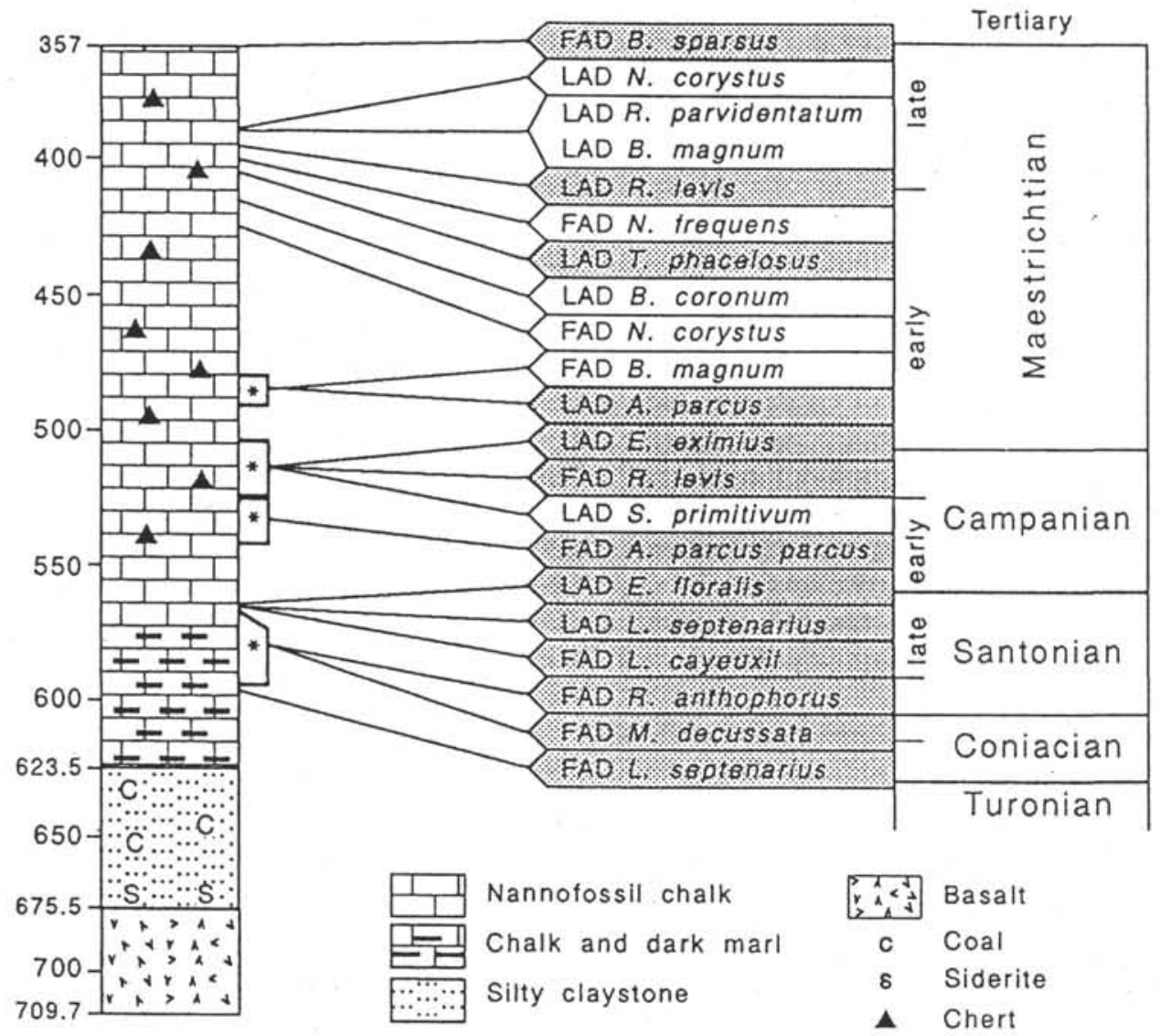

Figure 5. Placement of biostratigraphic events at Site 750. Boxes containing asterisks indicate stratigraphic uncertainty in event placement due to drilling strategy.

\section{SUMMARY AND COMPARISON OF SITES}

Age determinations and correlations based on calcareous nannofossil distributions are summarized in Figure 6.

The upper Maestrichtian is well represented only at Site 750. Nannofossil assemblages in this $38 \mathrm{~m}$ of nannofossil chalk are purely austral in character. The upper Maestrichtian assemblages lack the temperate marker species Micula murus and Lithraphidites quadratus as well as a number of taxa common in temperate to tropical upper Maestrichtian assemblages. As in the austral southern Atlantic (Wind, 1979b; Wise, 1983), Watznaueria barnesae is almost totally absent in the upper Maestrichtian. Prediscosphaera stoveri becomes very abundant just below the Cretaceous/Tertiary boundary in a manner similar to that described by Pospichal (1989) for Maud Rise and Broken Ridge. Biostratigraphic events in the Leg 120 material include the LAD of $N$. corystus and the synchronous(?) LAD of Repagalum parvidentatum and Biscutum magnum. The FAD of Nephrolithus frequens, used for an upper Maestrichtian zonal event in other areas, occurs in the lower Maestrichtian on Kerguelen. At Site 747, core and logging evidence indicates that the upper Maestrichtian was involved in a series of debris flow events.

The lower Maestrichtian is well represented at all three Leg 120 sites. At Site 747, approximately $80 \mathrm{~m}$ of nannofossil chalk were recovered, although logging data indicate that thin debris flow units persist down through the upper one-third of the lower Maestrichtian. Approximately $110 \mathrm{~m}$ of nannofossil chalk with minor amounts of chert is present at Site 750. The lower Maestrichtian consists of about $245 \mathrm{~m}$ of fine- to coarse-grained glauconitic grainstones and packstones at Site 748. Some of the record is absent at disconformities in these inner to outer neritic sediments. The inner neritic nature of some intervals combined with the intermittent silicification further diminishes the nannofossil record. Assemblages are generally depauperate (species richness of 17-22 taxa) relative to the other sites. This may be the result, in part, of the sparsity of nannofossils in these sediments. The chalks at the other two sites contain more abundant and relatively richer (approximately 30-35 taxa) assemblages. The presence of common Nephrolithus corystus, Biscutum magnum and/or $B$. coronum, Monomarginatus spp., and Misceomarginatus pleniporus and the absence of temperate taxa such as Quadrum trifidum, $Q$. gothicum, and Ceratolithoides aculeus indicate strongly austral conditions. Watznaueria barnesae appears sporadically in the upper part of the lower Maestrichtian but becomes a consistent minor component in the lower part. The lower Maestrichtian is separated from the upper Maestrichtian by the LAD of the cosmopolitan Reinhardtites levis. Eight other biostratigraphic events in the lower Maestrichtian are recognizable and appear to be correlative in the Kerguelen material. Of these, four are austral (FAD of Nephrolithus frequens below the LAD of $R$. levis; the LAD of $B$. coronum; and the FADs of $N$. corystus and B. magnum) and three are cosmopolitan (the LADs of Tranolithus phacelosus, Aspidolithus parcus parcus, and Eiffellithus eximius). Some of these can be reliably correlated with existing cosmopolitan or 
Table 3. Calcareous nannofossil distribution in the Upper Cretaceous of Site $\mathbf{7 5 0 .}$

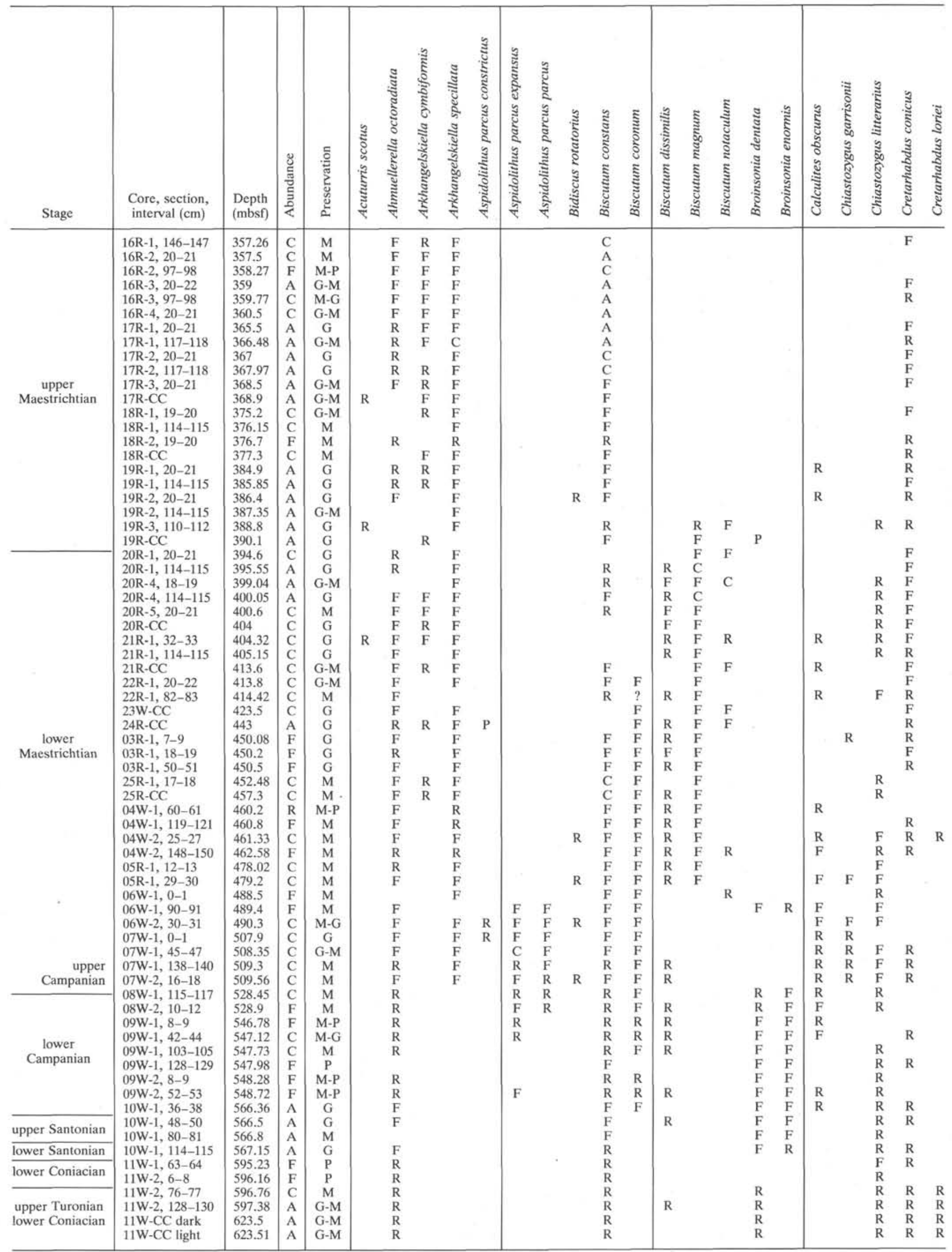




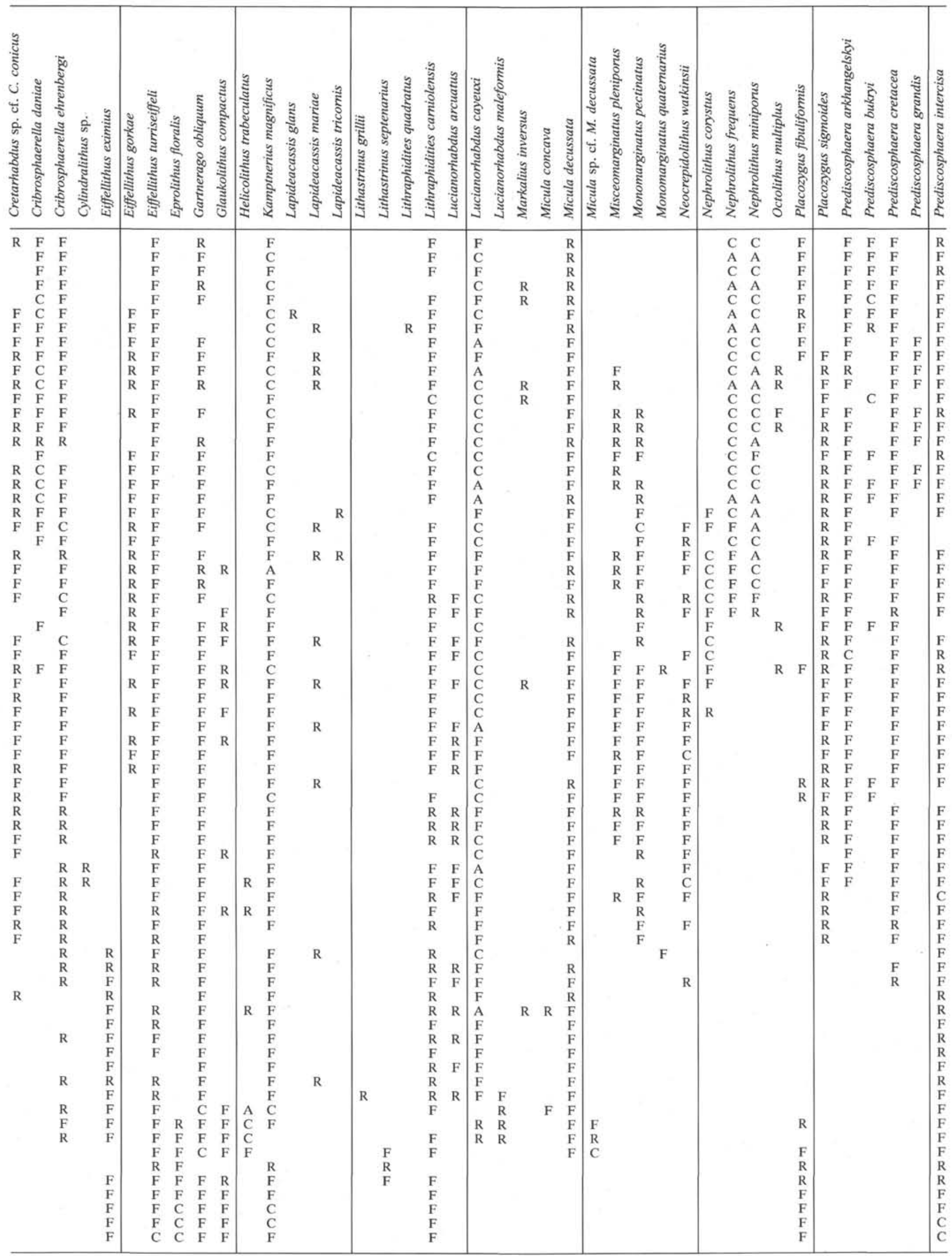




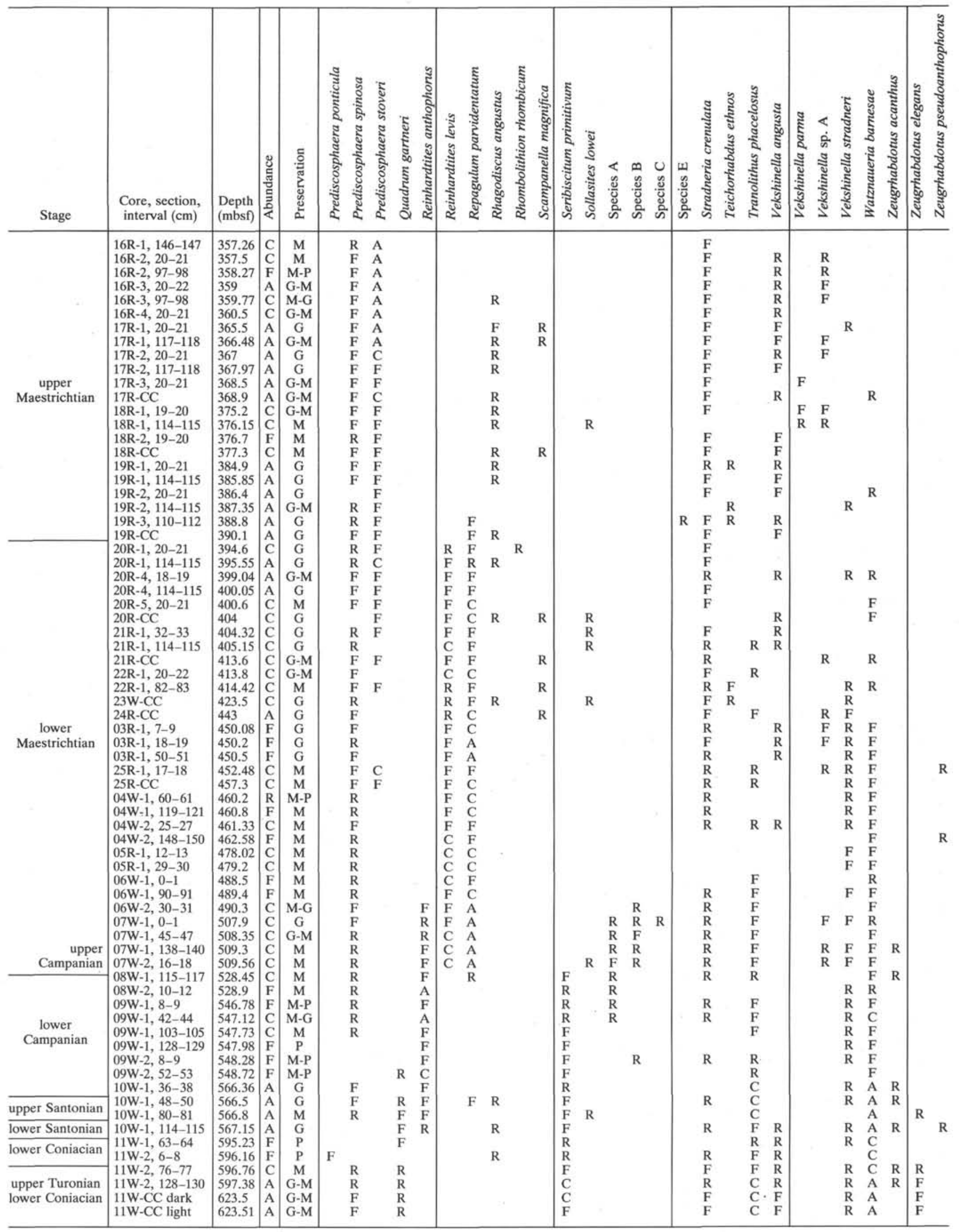

Note: Abundances assessed from smear slides. 


\section{Central Plateau Raggatt Basin}

\section{Site $747 \quad$ Site $748 \quad$ Site 750}

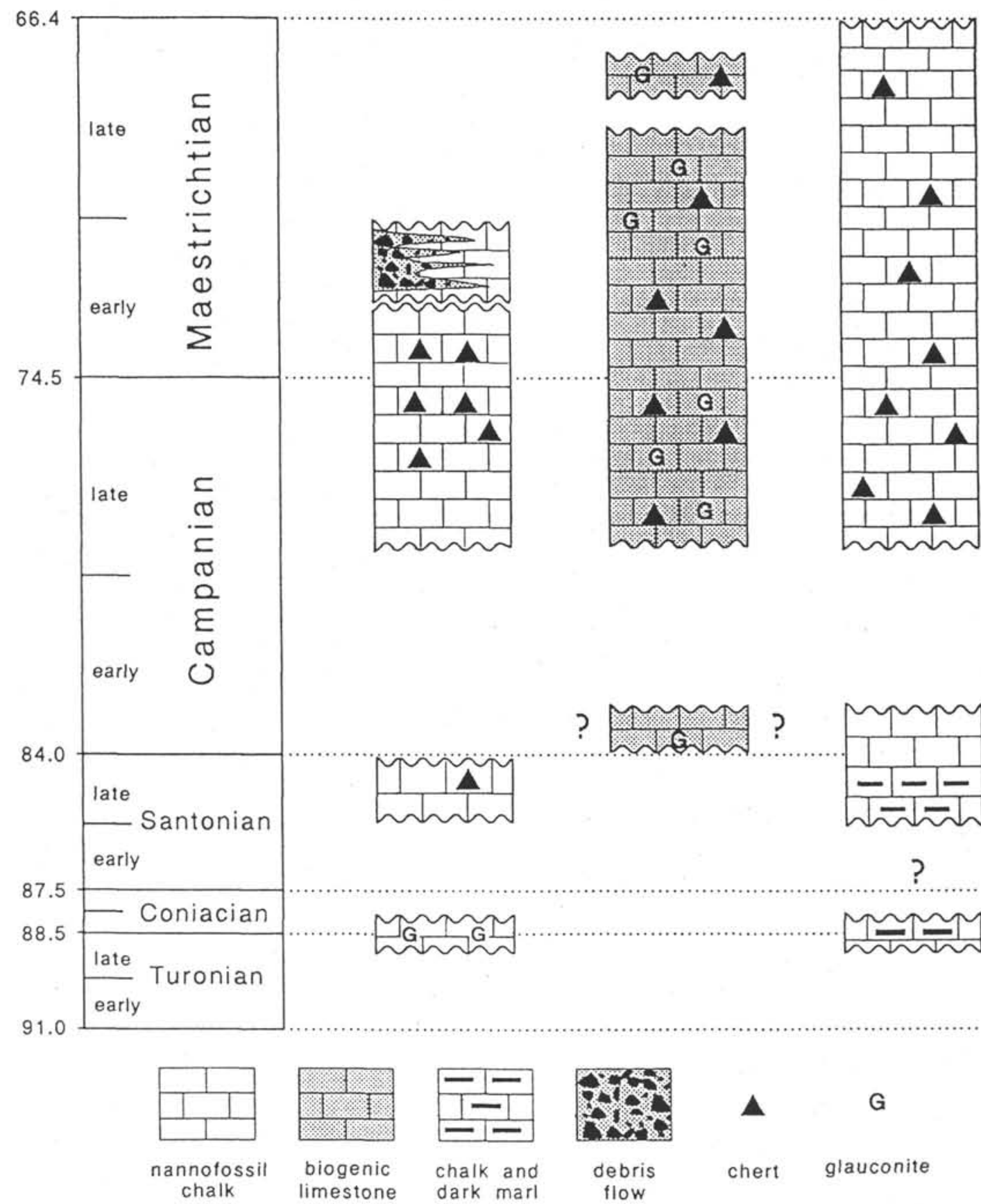

Figure 6. Distribution of major lithologic types in time illustrating the pattern of sedimentary rock preservation and omission. The thickness of the sedimentary packages as illustrated indicates their possible extension in time and does not relate to the actual thickness of the sedimentary units.

austral zonations, others may be useful only in local correlation on the Kerguelen Plateau.

The lower Campanian is represented by a single sample $(120-747 \mathrm{C}-9 \mathrm{R}-\mathrm{CC}, 16-17 \mathrm{~cm})$ having assemblages that suggest placement in the lowest Campanian. Given the core recovery, there may be as little as $10 \mathrm{~cm}$ or as much as $12 \mathrm{~m}$ of lower Campanian at Site 747. The lower Campanian at Site 748 consists of at least $56 \mathrm{~m}$ of glauconitic bioclastic packstone to wackestone, whereas it consists of about $30 \mathrm{~m}$ of nannofossil chalk at Site 750. Both sequences are bounded at the top by a disconformity of uncertain (and probably variable) hiatus. The upper Campanian at Site 748 is also truncated below by a disconformity with the Coniacian (Mohr and Gee, this volume). The presence of Seribiscutum primitivum in the lower Campanian at all three sites suggests austral affinities. 


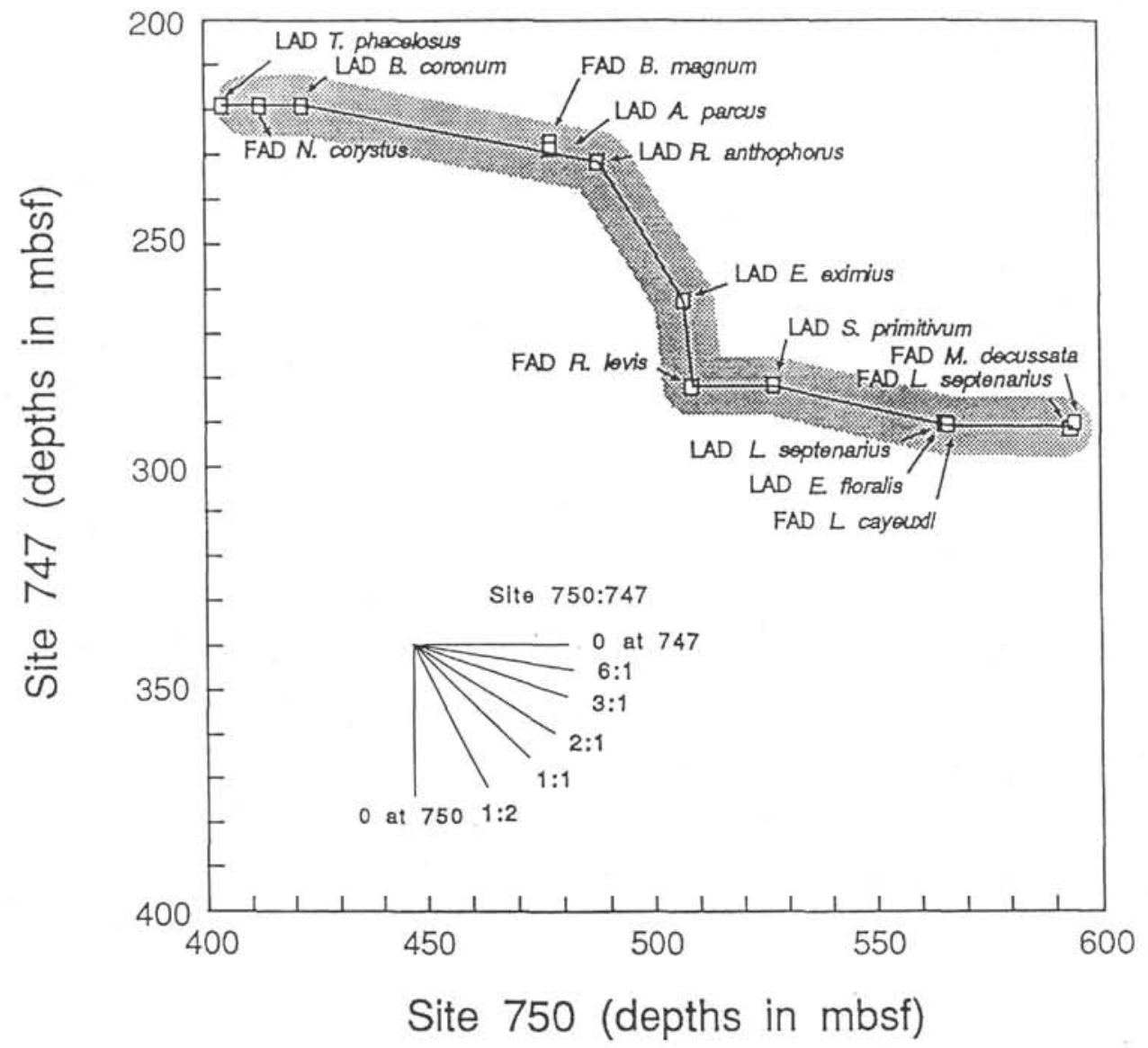

Figure 7. Graphic correlation of Site 747 vs. Site 750 .

Thin Santonian chalk intervals are present at both Sites 747 and 750. At Site 747, the upper Santonian consists of approximately $65 \mathrm{~cm}$ of nannofossil chalk; no lower Santonian was recovered by drilling operations. Both the upper and lower Santonian are present at Site 750. The nature of the core recovery in the Santonian at Site 750 (fragments of chert and chalk) makes it difficult to estimate thickness, although it is clear that the upper Santonian is thin $(>1 \mathrm{~m})$. The thickness of the lower Santonian cannot be estimated because the lower interval was not cored. The assemblages are less clearly austral in character, although the presence of common Seribiscutum primitivum demonstrates their austral affinities. The LADs of Eprolithus floralis and Lithastrinus septenarius and the FAD of Lucianorhabdus cayeuxii (cosmopolitan biostratigraphic events) are used for subdivision of this interval. Marthassterites furcatus, a common and biostratigraphically useful taxon in temperate areas as well as on the Falkland Plateau, is only sporadically present in the Santonian of the Kerguelen Plateau.

The upper Coniacian is apparently absent at the sites drilled. The upper Turonian to lower Coniacian is represented at both Sites 747 and 750 . At the former, it is a thin $(10 \mathrm{~cm})$, glauconitic bioclastic packstone; at the latter, it is a thin (60 $\mathrm{cm}$ ) marly chalk. The presence of Thiersteinia ecclesiastica suggests austral affinities, although the assemblages are similar to temperate ones in other aspects.

A well-calibrated nannofossil geochronology would help in making a direct comparison of the sites and computation of rock accumulation rates. Unfortunately, an insufficient number of applicable Upper Cretaceous nannofossil events have been correlated to the absolute time scale to allow accurate sediment accumulation rates. In lieu of direct geochronologic correlations, which would yield true rock accumulation rates, graphic correlations between sites have been prepared that yield differences in relative rock accumulation rates.

Biostratigraphic evidence indicates that Site 750 has the most complete pelagic record of the Upper Cretaceous and therefore serves as a standard for comparison using graphic correlation. The upper Maestrichtian is recorded by a disconformity at Site 748 and by a disconformity and a debrisflow unit (in part) at Site 747. The upper lower Maestrichtian is thin at both Sites 747 and 748 relative to Site 750 (Figs. 7-8). The sequence at Site 747 appears to be thin owing to lower rates of rock accumulation, whereas at Site 748 , its thinness is the result of truncation of the upper lower Maestrichtian by a disconformity. The lower part of the lower Maestrichtian is significantly expanded at Site 748 relative to both Sites 747 and 750 , as is evident in the nearly vertical lines of correlation in Figures 7-8. This interval at Site 748 consists of glauconitic, molluscan-bryozoan grainstones, and packstones. The upper Turonian through upper Campanian of Sites 747 and 750 consists of intervals of pelagic sediments (chalks with minor chert) interrupted by at least two disconformities.

\section{AUSTRAL BIOSTRATIGRAPHIC EVENTS}

Early work on the upper Cretaceous nannofossils of the Southern Ocean (e.g., Wise and Wind, 1977; Wind, 1979a, 1979b; Wise, 1983) identified a group of austral assemblages that differ significantly from those of temperate and boreal 


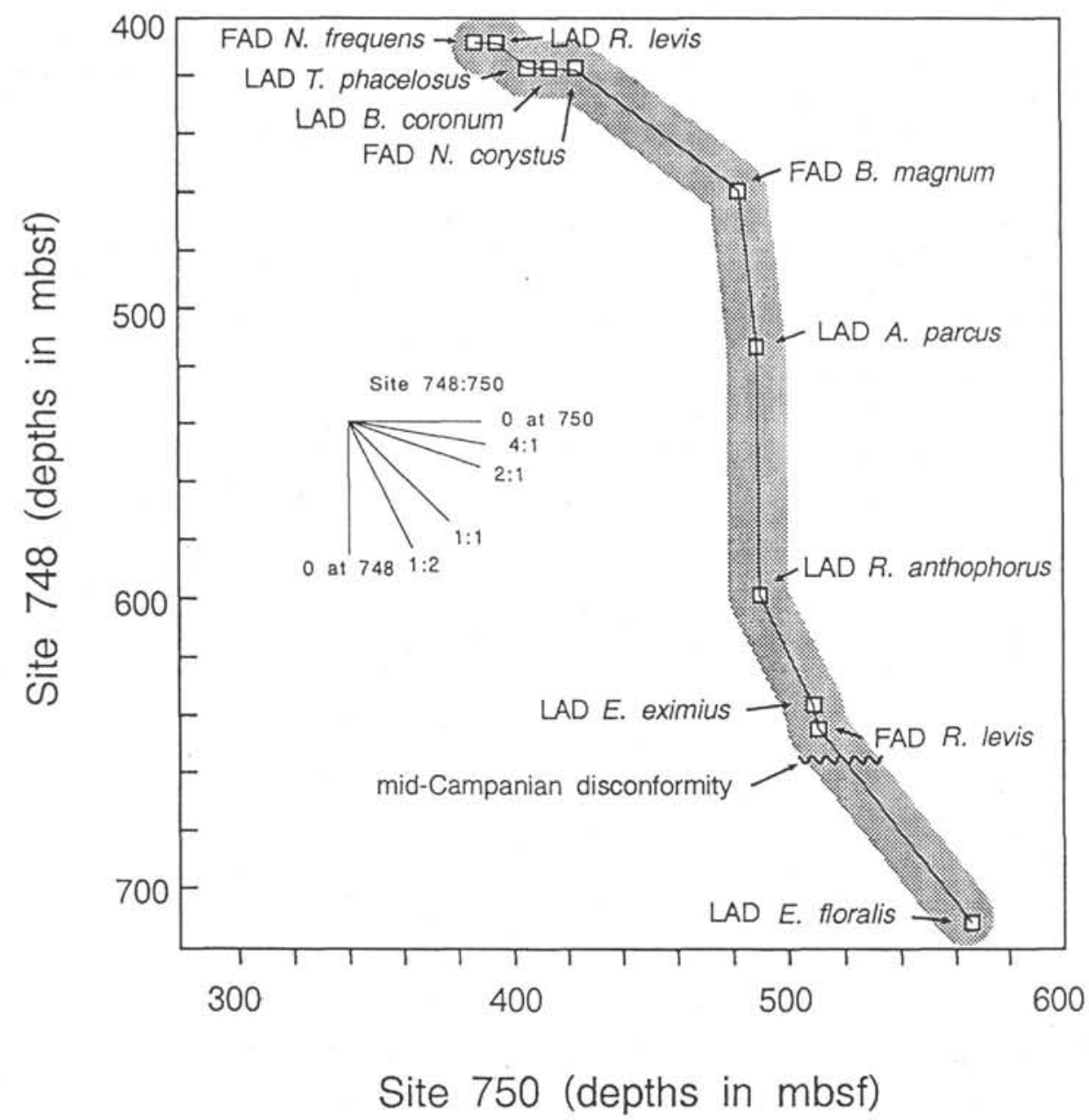

Figure 8. Graphic correlation of Site 748 vs. Site 750 .

areas. The distinctive character of these assemblages, as well as a lack of information on the correlation of these austral sites to temperate areas, resulted in the establishment of an austral nannofossil zonation for the Upper Cretaceous.

The abundance of austral taxa (such as Biscutum magnum and Biscutum coronum) and the absence or rarity of temperate taxa (such as Lithraphidites quadratus, Micula murus, and Quadrum trifidum) led them to propose zonation schemes for the Campanian-Maestrichtian that depend largely upon the austral species. Assemblages from the Falkland Plateau constituted most of the data on which these zonations were based (Wise and Wind, 1977; Wind, 1979a, 1979b; Wise, 1983). Wind (1979a, 1979b) used Indian Ocean DSDP Sites 217 and 249, where both temperate and austral species occur, to calibrate his high-latitude zonation for the Campanian-Maestrichtian but included no "cosmopolitan" taxa in his zonation. Subsequently, Wind and Wise (1983) used the distribution of three cosmopolitan taxa (Tranolithus phacelosus (as " $T$. orionatus"), Reinhardtites sp. aff. R. anthophorus, and Reinhardtites levis) to recognize the $T$. phacelosus and $R$. levis cosmopolitan Zones of Sissingh (1977) in the upper Campanian to lower Maestrichtian of Falkland Plateau DSDP and ARA Islas Orcadas sites and to calibrate the B. coronum and B. magnum zones of Wind (1979a) to the zonation of Sissingh (1977). This zonation scheme has been used with only slight emendation or modification by Wise (1988) and Pospichal and Wise (1990).

The zonation of the Turonian through lower Campanian by Wise $(1983,1988)$ uses a mixture of both austral and cosmo- politan taxa. Cosmopolitan events include the FADs of Kamptnerius magnificus (upper Turonian), Marthasterites furcatus (upper Turonian) and the LADs of Eprolithus floralis (upper Santonian) and $M$. furcatus (lower Campanian). Austral events include the LAD of Thiersteinia ecclesiastica (Coniacian-Santonian, undifferentiated) and the FAD of $\mathrm{Ge}$ phyrobiscutum diabolum (lower Campanian).

The Upper Cretaceous sections drilled on Leg 120 are the most complete and contain the best preserved nannofossil assemblages of any recovered to date from deep sea drilling in the Southern Ocean. Nevertheless, poor recovery caused by drilling complications has kept these sections from qualifying as "ideal" for solving all the problems in Southern Ocean nannofossil biostratigraphy. However, when combined with previous work in the Atlantic sector, a large body of data emerges that allows a sequence of biostratigraphic events to be proposed, which, in general, yield a high degree of temporal resolution. Some of these events are useful throughout the Southern Ocean, whereas others are only of local utility. Rather than propose a new zonation, which may be premature in light of additional information from drilling on Leg 121, I have chosen to use a sequence of biostratigraphic events that can be used reliably on the Kerguelen Plateau. These are illustrated in Figure 2 and discussed below.

The Maestrichtian is divided by the use of a combination of austral and cosmopolitan biostratigraphic events. The top of the Maestrichtian is marked by the FAD of Biantholithus sparsus, following the suggestion of Perch-Nielsen (1979a). 
The upper Maestrichtian is subdivided by the LADs of Nephrolithus corystus, Repagalum parvidentatum, and Biscutum magnum. According to the evidence at Site 750, the latter two datums appear to be isochronous. At Leg 113 Site 690, the only other site where the LAD of $B$. magnum is well preserved, $R$. parvidentatum was not reported (Pospichal and Wise, 1990). The interval between the LADs of $N$. corystus and $R$. parvidentatum/B. magnum probably does not represent a long period of time. At Site 750 , these two levels are separated by $<1 \mathrm{~m}$ of nannofossil chalk. At Leg 113 Site 690 , this same interval comprises $<2.5 \mathrm{~m}$ of chalk (Pospichal and Wise, 1990). The LAD of Reinhardtites levis is used to approximate the upper/lower Maestrichtian boundary.

The lower Maestrichtian is subdivided by the use of eight datum levels. The uppermost, the FAD of Nephrolithus frequens, is obviously diachronous on a global scale (Worsley and Martini, 1970; Wind, 1979a; Pospichal and Wise, 1990; Crux, 1990), and its placement here is useful only for local correlation. Sissingh (1977) designated the gap between the (upper) FAD of $N$. frequens and the (lower) LAD of Reinhardtites levis as the Arkhangelskiella cymbiformis Interval Zone. Pospichal and Wise (1990) demonstrated that the FAD of $N$. frequens and the LAD of R. levis are nearly isochronous (during Chron 31R) on Maud Rise. At Site 750, there is a minimum of $6 \mathrm{~m}$ of overlap (as opposed to a gap) in the species ranges. This overlap is interpreted as illustrating the markedly diachronous nature of the FAD of $N$. frequens relative to the globally parasynchronous LAD of $R$. levis (Fig. 3). Both species are fairly common within this interval, and no evidence of reworking is present. Drilling disturbance at this site prohibited a continuous paleomagnetic record. However, a brief normal-reversed-normal sequence near the top of Core 120-750-20R has been correlated with Chron 32N (Schlich, Wise, et al., 1989, p. 307). If this correlation is correct, it would clearly demonstrate the overlap of the diachronous $N$. frequens with $R$. levis. One should note, however, that these paleomagnetic correlations were made based, at least in part, on biostratigraphic considerations.

The remaining six lower Maestrichtian datum levels are a combination of austral and cosmopolitan. These include (from upper to lower): the LADs of Tranolithus phacelosus (cosmopolitan) and Biscutum coronum (austral), the FADs of Nephrolithus corystus (austral) and Biscutum magnum (austral), and the LADs of Aspidolithus parcus (cosmopolitan) and Eiffellithus eximius (cosmopolitan). The LAD of $T$. phacelosus was difficult to pinpoint in a cursory examination owing to its rarity near the top of its range in the Kerguelen material. The LAD of the $A$. parcus group also was difficult to establish in poorly preserved material using the light microscope because of the rarity of $A$. parcus constrictus and the large number of Arkhangelskiella specillata generally found in Southern Ocean samples. Examination with the SEM is occasionally necessary for a definitive placement. The other datum levels, however, were easily and rapidly recognized in all but the worst preserved material. The recognition and use of the cosmopolitan events allows this biostratigraphic sequence to be directly correlated with the temperate zonation schemes.

The Campanian/Maestrichtian boundary was placed between the FAD of Reinhardtites levis and the LAD of Eiffellithus eximius. As with all other Southern Ocean deep sea drilling sites, most of the Campanian on the Kerguelen Plateau is missing across a major disconformity (Watkins et al., 1989). As a result, only four biostratigraphic events were recognized for this interval: the FAD of $R$. levis, the LAD of $S$. primitivum, the FAD of Aspidolithus parcus parcus, and the LAD of Eprolithus floralis. The placement of the LAD of
$S$. primitivum was uncertain as this event was associated with the mid-Campanian disconformity at all three sites. At Site $747, S$. primitivum and $R$. levis overlap throughout most of Core 120-747C-9 except in the basal sample. Seribiscutum primitivum occurs with rare Quadrum trifidum and Quadrum gothicum and with common specimens of Reinhardtites anthophorus similar to $R$. sp. aff. $R$. anthophorus of Sissingh (1977) in Sample 120-747C-9R-CC, 6-7 cm. This placed the LAD of $S$. primitivum in an interval equivalent to the lower $Q$. trifidum Zone (CC22a-CC22b) of Sissingh (1977) and PerchNielsen (1985). However, this sample is directly above a major disconformity (in Section 120-747C-9R-CC), and it is most probable that the rare specimens of $S$. primitivum are reworked from the underlying upper Santonian. Reworking is also the most likely explanation for the very rare occurrence of $S$. primitivum in samples just above the FAD of $R$. levis at Site 748. At Site 750, within the most expanded pelagic section, the LAD of $S$. primitivum and the FAD of $R$. levis occur in adjacent samples and are separated by a lithologic change. The record of Site 750 indicates that the stratigraphic range of $S$. primitivum and/or $R$. levis is truncated by the mid-Campanian disconformity. Although the placement of the FAD of $R$. levis is well known from other areas, the level of the LAD of $S$. primitivum is still uncertain as it occurs later in the Southern Ocean than elsewhere. The LAD of $E$. floralis is used to approximate the Santonian/Campanian boundary, following Perch-Nielsen (1979b).

An additional biostratigraphic event observed in the Southern Ocean is the acme of Helicolithus trabeculatus associated with the LAD of $E$. floralis. In the Atlantic sector of the Southern Ocean, Wise (1983) reported abundant to rare $H$. trabeculatus (as Eiffellithus trabeculatus) in eight consecutive samples (Samples 71-511-39R-4, 35-36 cm, through -42R-1, $112-113 \mathrm{~cm} ; 333-358 \mathrm{mbsf})$ in the lower Campanian. The only other reported occurrence of this taxon is one sample in the upper Turonian. The base of this interval of high abundance is approximately $8 \mathrm{~m}$ above the LAD of $E$. floralis. From studies on the northeastern slope of the Northeast Georgia Rise, Crux (1990) reports $H$. trabeculatus in only two samples (rare in Sample 114-700B-51R-CC and common in Sample 114-700B$52 \mathrm{R}-\mathrm{CC}$ ) in a section that spans the upper Santonian through Maestrichtian. These samples straddle the LAD of E. floralis, which occurs in Sample 114-700B-52R-CC. In the Indian sector, an acme of $H$. trabeculatus straddles the LAD of $E$. floralis in Holes 747C and 750B, which penetrated the Santonian/Campanian boundary.

The upper Turonian-Santonian datum levels used are all cosmopolitan and consist of a subset of those used for the "cosmopolitan" zonation of Sissingh (1977) and Perch-Nielsen $(1979 b, 1985)$. These datums include (from upper to lower): the LAD of Lithastrinus septenarius (upper Santonian), the FADs of Lucianorhabdus cayeuxii (upper Santonian), Reinhardtites anthophorus (lower Santonian), Micula decussata (upper Coniacian), and L. septenarius (lower Coniacian). The range of Marthasterites furcatus, a "cosmopolitan" taxon that was used in the Atlantic sector of the Southern Ocean by Wise and Wind (1977) and by Wise (1983, 1988), was not used on Kerguelen because of its extreme rarity. S. W. Wise (pers. comm., 1990) suggested that the rarity of $M$. furcatus in the Kerguelen material is a reflection of the excellent preservation of the Upper Cretaceous Kerguelen assemblages. These rare specimens are "swamped" by the other carbonate preserved in these samples. On the Falkland Plateau, the dissolution-resistant $M$. furcatus is concentrated to biostratigraphically useful abundances by diagenesis. If Wise is correct, it follows that $M$. furcatus was 
a rare component of Coniacian and Santonian Southern Ocean nannoplankton communities.

\section{PALEOBIOGEOGRAPHY OF AUSTRAL NANNOFOSSILS}

Worsley and Martini (1970) first suggested significant nannofossil provincialism in the Upper Cretaceous ocean with their documentation of the bipolar distribution of Nephrolithus frequens and the tropical-subtropical restriction of Micula murus during the late Maestrichtian. Bukry (1973) used the absence of Watznaueria barnesae and the abundance of $N$. frequens and Kamptnerius magnificus to denote polar assemblages in samples from the Upper Cretaceous of DSDP Site 207 (Tasman Sea), New Zealand, and West Siberia. The first indication of provincialism in the lower part of the Upper Cretaceous was the discovery of the high-latitude species Seribiscutum primitivum by Thierstein (1974). Thierstein (1976) noted one species restricted to the austral and boreal realms ( $S$. primitivum) and several that are more abundant in high-latitude sites.

Drilling on the Falkland Plateau yielded a large number of new taxa (Wise and Wind, 1977) and spurred greater interest in the degree of nannofossil provincialism present through the Late Cretaceous. Wind (1979a, 1979b) noted the most common taxa in Southern Ocean (Atlantic and Indian sectors) Campanian-Maestrichtian assemblages (Table 4). $\mathrm{He}$ attempted to assess quantitatively the provincialism in the Southern Ocean using numerical abundances of selected taxa. An inverse relationship of the distributions of Micula decussata vs. (Watznaueria barnesae + Cyclagelosphaera margerelii) was noted, the latter group being abundant in the tropics and absent (or very rare) in the austral ocean. Wind (1979a, 1979b) also recognized a second paleolatitudinally dependent distribution trend in the abundance/presence of species of Biscutum. Low- and middle-latitude sites contain common $B$. constans, whereas high-latitude sites have few $B$. constans but common $B$. coronum and/or B. magnum.

Thierstein (1981) identified 13 austral/boreal taxa (Table 4) based on an examination of 243 upper Campanian through upper Maestrichtian assemblages from outcrops and deep sea drilling. These species included several (e.g., Seribiscutum primitivum, Misceomarginatus pleniporus) that were restricted to the austral province during the later Cretaceous. Several other taxa (e.g., Kamptnerius magnificus, Micula decussata) exhibited enhanced abundances at high latitudes during this time. Finally, he noted seven taxa that were absent or unusually rare in the austral province during the Late Cretaceous.

Wise (1983) studied additional core material from the Falkland Plateau (DSDP Leg 71) and compiled a long list of "austral" taxa. Some of these have been observed only on the Falkland Plateau and are not included in Table 4. No differentiation based on age was designated by Wise, so that Watznaueria barnesae, which is common in the lower Upper Cretaceous but absent and demonstrably "australophobic" during the Maestrichtian, was included on the list of austral taxa. Work on the existing Upper Cretaceous material before ODP drilling in the Southern Ocean was summarized and synthesized by Wise (1988). Several austral taxa were mentioned, and a new austral taxon from the lower Campanian (Gephyrobiscutum diabolum) was introduced.

Pospichal and Wise (1990) have examined the Maestrichtian nannofossils from Maud Rise (Weddell Sea) as a result of the first ODP venture into the Southern Ocean (Leg 113). Table 3 in Pospichal and Wise (1990) consists of a comparison of the Maud and Falkland Maestrichtian assemblages. Examination indicates that the Maud Rise assemblages are similar to those on the Falkland Plateau in all respects except that the apparent species richness of holococcoliths (Calyptrosphaeraceae) is much lower on Maud Rise than on the Falkland Plateau. This is most likely the result of the superior preservation at the Falkland sites, as additional species have been found in the best preserved Maud Rise samples (J. Pospichal, pers. comm., 1990).

The rich assemblages from the Kerguelen Plateau allow comparison of the Indian sector and the Atlantic sector of the Southern Ocean from Coniacian through Maestrichtian (Table 4 , column 10). The Maestrichtian assemblages are quite similar in both sectors, as reflected by the similarity of the taxa found on Kerguelen, Maud Rise, and the Falkland Plateau. As with Maud Rise, Kerguelen assemblages have fewer holococcolith species than do the Falkland assemblages. This may be a reflection of the pristine preservation of the Falkland Maestrichtian assemblages. The upper Campanian from the Kerguelen and Falkland plateaus are also similar in all significant respects. Indeed, the striking similarity of the nannofossil assemblages from both the Atlantic and Indian sectors of the Southern Ocean indicates that the Falkland Plateau Nannofossil Biogeographic Province of Wind (1979b) is better characterized as an austral nannofossil realm that developed during the late Campanian and persisted, at least, until the end of the Cretaceous.

Both the Atlantic and Indian sectors have a significant disconformity marking the mid-Campanian (Watkins et al., 1989). Below this disconformity, the Coniacian through lower Campanian assemblages are distinctly austral but differ from one another in significant ways. The upper lower Campanian of the Falklands contains very high abundances of Gephyrobiscutum diabolum (Wise, 1988), whereas this species has not been observed in the Kerguelen material. This may be caused by a larger hiatus on Kerguelen, which removed the $G$. diabolum Subzone of Wise (1988), or it may indicate that $G$. diabolum is endemic to the Atlantic sector (or to the Falklands). Marthasterites furcatus is common enough in the Falklands to be used as a zonal marker (Wise and Wind, 1977; Wise, 1983, 1988) whereas it is almost absent from Kerguelen. This may be the result of differential preservation (as discussed in the "Austral Biostratigraphic Events" section, this chapter) or may reflect a true biogeographic difference. Thiersteinia ecclesiastica, a Coniacian-Santonian subzonal marker in the Atlantic (Wise, 1983, 1988) is too rare to be useful on Kerguelen. This latter difference may be related more to facies differences and/or disconformities in the Kerguelen record, as Thierstein (1974) reports common to abundant "?Broinsonia furtiva" $(=T$. ecclesiastica; see Wise, 1983) in the upper Coniacian and Santonian of the Naturaliste Plateau.

Clearly, the degree of provincialism was much greater in the later part of the Late Cretaceous than in the early Late Cretaceous. Endemism was much greater in the later Cretaceous. At least ten species are known to have been endemic to the austral realm during the late Campanian through Maestrichtian as compared with only three (two of which have short ranges) in the Coniacian to early Campanian. Several species that were common constituents of later Cretaceous assemblages in most areas (e.g., W. barnesae) were excluded from the Maestrichtian Southern Ocean, whereas these were common in the earlier Late Cretaceous Southern Ocean.

The demarcation between the subtle provincialism of the Coniacian through early Campanian and the severe provincialism of the late Campanian and Maestrichtian is the midCampanian disconformity. The event(s) that either caused or are masked by the mid-Campanian disconformity must have involved a fundamental reorganization of circulation in the Southern Ocean. The Southern Ocean, which was linked to the temperate seas by a weak ecologic gradient during the 
Table 4. Taxa previously attributed to either "australophobic" (absent or unusually rare in southern high latitudes) and "australophilic" (present and/or unusually abundant in southern high latitudes) group.

\begin{tabular}{|c|c|c|c|c|c|c|c|c|c|c|}
\hline & \multicolumn{10}{|c|}{ Previous attribution } \\
\hline & 1 & 2 & 3 & 4 & 5 & 6 & 7 & 8 & 9 & 10 \\
\hline \multicolumn{11}{|l|}{ "Australophobic" taxa } \\
\hline Aspidolithus p. contrictus & & & & & & & & & & $\mathrm{X}$ \\
\hline Biscutum constans $(\mathrm{M})$ & & & & & $\mathrm{X}$ & & & & & \\
\hline Ceratolithoides aculeus & & & & $\mathrm{X}$ & & $\mathrm{X}$ & & & & $\mathrm{X}$ \\
\hline Cretarhabdus surirellus & & & & & & $\mathrm{X}$ & & & & \\
\hline Cylindralithus serratus & & & & & & $\mathrm{X}$ & & & & $\mathrm{X}$ \\
\hline Lithraphidites quadratus & & & & & & $\mathrm{X}$ & & & & $\mathrm{X}$ \\
\hline Lithraphidites spp. & & & & $\mathrm{X}$ & & & & & & $\mathrm{X}$ \\
\hline Micula murus & $\mathrm{X}$ & & $\mathrm{x}$ & & & $\mathrm{X}$ & & & & $\mathrm{X}$ \\
\hline Quadrum sissinghii & & & & $\mathrm{X}$ & & & & & & $\mathrm{X}$ \\
\hline Quadrum trifidum & & & & & & $\mathrm{X}$ & & & & $\mathrm{X}$ \\
\hline Watznaueria barnesae (M) & & $\mathrm{X}$ & & & $\mathrm{X}$ & $\mathrm{X}$ & & & & $\mathrm{X}$ \\
\hline \multicolumn{11}{|l|}{ "Australophilic" taxa } \\
\hline Acuturris scotus & & & & & $\mathrm{X}$ & & $\mathrm{X}$ & & $\mathrm{X}$ & $\mathrm{X}$ \\
\hline Ahmuellerella octoradiata & & & $\mathrm{X}$ & & $\mathrm{X}$ & $\mathrm{X}$ & $\mathrm{X}$ & & $\mathrm{X}$ & $\mathrm{X}$ \\
\hline Arkhangelskiella cymbiformis & & $X$ & & & $\mathrm{X}$ & $\mathrm{X}$ & & & $\mathrm{X}$ & $\mathrm{X}$ \\
\hline Arkhangelskiella specillata & & & & & & & $\mathrm{X}$ & & $\mathrm{X}$ & $\mathrm{X}$ \\
\hline Aspidolithus parcus expansus & & & & & & & $\mathrm{X}$ & & & $\mathrm{X}$ \\
\hline Aspidolithus parcus parcus & & & & & & & $\mathrm{X}$ & & & $\mathrm{X}$ \\
\hline Biscutum constans & & & & & & $\mathrm{X}$ & $\mathrm{X}$ & & & $\mathrm{X}$ \\
\hline Biscutum coronum & & & & & $\mathrm{X}$ & & $\mathrm{X}$ & & $\mathrm{X}$ & $\mathrm{X}$ \\
\hline Biscutum dissimilis & & & & $\mathrm{X}$ & $\mathrm{X}$ & & $\mathrm{X}$ & & $\mathrm{X}$ & $\mathrm{X}$ \\
\hline Biscutum magnum & & & & & $\mathrm{X}$ & & $\mathrm{X}$ & & $\mathrm{X}$ & $\mathrm{X}$ \\
\hline Biscutum notaculum & & & & & $\mathrm{X}$ & & & & $\mathrm{X}$ & \\
\hline Braarudosphaera bigelowii & & & $\mathrm{X}$ & & & & $\mathrm{X}$ & & & \\
\hline Broinsonia dentata & & & & & & & $\mathrm{X}$ & & & $\mathrm{X}$ \\
\hline Calculites obscurus & & & $\mathrm{X}$ & & & & $\mathrm{X}$ & & $\mathrm{X}$ & $\mathrm{X}$ \\
\hline Cretarhabdus conicus & & & & & $\mathrm{X}$ & & $\mathrm{X}$ & & $\mathrm{X}$ & $\mathrm{X}$ \\
\hline Cretarhabdus surirellus & & & & & & & $\mathrm{X}$ & & $\mathrm{X}$ & $\mathrm{X}$ \\
\hline Cribrosphaerella daniae & & & & & $\mathrm{X}$ & & & & $\mathrm{X}$ & $\mathrm{X}$ \\
\hline Cribrosphaerella ehrenbergii & & & & & & & $\mathrm{X}$ & & $\mathrm{X}$ & $\mathrm{X}$ \\
\hline Eiffellithus eximius & & & & & & & $\mathrm{X}$ & & & $\mathrm{X}$ \\
\hline Eiffellithus turriseiffelii & & & & $\mathrm{X}$ & $\mathrm{X}$ & $\mathrm{X}$ & $\mathrm{X}$ & & $\mathrm{X}$ & $\mathrm{X}$ \\
\hline Eprolithus floralis & & & & & & & $\mathrm{X}$ & & & $\mathrm{X}$ \\
\hline Gartnerago obliquum & & & $\mathrm{X}$ & & $\mathrm{X}$ & $\mathrm{X}$ & & & $\mathrm{X}$ & $\mathrm{X}$ \\
\hline Gephyrobiscutum diabolum & & & & & & & & $\mathrm{X}$ & & \\
\hline Glaukolithus compactus & & & & & & & & & $\mathrm{X}$ & $\mathrm{X}$ \\
\hline Kamptnerius magnificus & & $\mathrm{x}$ & $\mathrm{X}$ & $\mathrm{X}$ & $\mathrm{X}$ & $\mathrm{X}$ & $\mathrm{X}$ & & $\mathrm{X}$ & $\mathrm{X}$ \\
\hline Lapideacassus mariae & & & & & & & $\mathrm{X}$ & & $\mathrm{X}$ & $\mathrm{X}$ \\
\hline Lapideacassus tricornis & & & & & & & & & $\mathrm{X}$ & $\mathrm{X}$ \\
\hline Lucianaorhabdus cayeuxii & & & $\mathrm{X}$ & & $\mathrm{X}$ & $\mathrm{X}$ & $\mathrm{X}$ & & $\mathrm{X}$ & $\mathrm{X}$ \\
\hline Micula decussata & & & $\mathrm{X}$ & & $\mathrm{X}$ & & $\mathrm{X}$ & & $\mathrm{X}$ & $\mathrm{X}$ \\
\hline Misceomarginatus pleniporus & & & & $\mathrm{X}$ & $\mathrm{x}$ & $\mathrm{X}$ & $\mathrm{X}$ & & $\mathrm{X}$ & $\mathrm{X}$ \\
\hline Monomarginatus pectinatus & & & & $\mathrm{x}$ & $\mathrm{x}$ & & $\mathrm{X}$ & & $\mathrm{X}$ & $\mathrm{X}$ \\
\hline Monomarginatus quaternarius & & & & $\mathrm{X}$ & $\mathrm{X}$ & & $\mathrm{X}$ & & $\mathrm{X}$ & $\mathrm{X}$ \\
\hline Nephrolithus corystus & & & & & $\mathrm{X}$ & & $\mathrm{X}$ & & $\mathrm{X}$ & $\mathrm{X}$ \\
\hline Nephrolithus frequens & $\mathrm{X}$ & $\mathrm{X}$ & $\mathrm{X}$ & $\mathrm{X}$ & $\mathrm{X}$ & $\mathrm{X}$ & $\mathrm{X}$ & & $\mathrm{X}$ & $\mathrm{X}$ \\
\hline Octocyclus reinhardtii & & & & & & & $\mathrm{X}$ & & $\mathrm{X}$ & $\mathrm{X}$ \\
\hline Prediscosphaera cretacea & & & & & $\mathrm{X}$ & & $\mathrm{X}$ & & $\mathrm{X}$ & $\mathrm{X}$ \\
\hline Prediscosphaera grandis & & & & & & & $\mathrm{X}$ & & & \\
\hline Prediscosphaera stoveri & & & & & & & & & $\mathrm{X}$ & $\mathrm{X}$ \\
\hline Prediscosphaera spinosa & & & & & $\mathrm{X}$ & $\mathrm{X}$ & $\mathrm{X}$ & & $\mathrm{X}$ & $\mathrm{X}$ \\
\hline Reinhardtites anthophorus & & & & & $\mathrm{X}$ & $\mathrm{X}$ & & & & $\mathrm{X}$ \\
\hline Reinhardtites levis & & & & & & & & & $X$ & $\mathrm{X}$ \\
\hline Repagalum parvidentatum & & & & & & & $\mathrm{x}$ & $\mathrm{X}$ & & $\mathrm{X}$ \\
\hline Seribiscutum primitivum & & & $\mathrm{X}$ & $\mathrm{X}$ & $\mathrm{X}$ & $\mathrm{X}$ & $\mathrm{X}$ & $\mathrm{X}$ & & $\mathrm{X}$ \\
\hline Thiersteinia ecclesiastica & & & & & & & $\mathrm{X}$ & $\mathrm{X}$ & & $\mathrm{X}$ \\
\hline Tranolithus phacelosus & & & & & $\mathrm{X}$ & & $\mathrm{X}$ & & $\mathrm{X}$ & $\mathrm{X}$ \\
\hline
\end{tabular}

Note: The (M) following B. constans and W. barnesae in the "australophobic" category indicate that they are absent or unusually rare only in the Maestrichtian. References or attributions are as follows: $1=$ Worsley and Martini (1970), $2=$ Bukry (1973), $3=$ Thierstein (1976), $4=$ Wise and Wind (1977), $5=$ Wind (1979b), $6=$ Thierstein (1981), $7=$ Wise (1983), $8=$ Wise (1988), $9=$ Pospichal and Wise $(1990)$, and $10=$ this study. 
Coniacian through early Campanian, was ecologically decoupled from the temperate seas by the mid-Campanian "event." The ecological isolation that resulted allowed several lineages (e.g., Nephrolithus, Monomarginatus, Biscutum) to radiate and give rise to numerous endemic species.

\section{CONCLUSIONS}

The rich nannofossil assemblages from the central and southern Kerguelen Plateau constitute the most complete and best preserved record of Upper Cretaceous nannofossil history from the Austral Realm recovered to date. Examination of this record and comparison with previous work in the Southern Ocean Upper Cretaceous lead to several conclusions.

Sections at Sites 747 and 750 (Figs. 3 and 5) contain pelagic records spanning the upper Turonian(?)-lower Coniacian through Maestrichtian. Significant disconformities occur in the mid-Campanian, lower Santonian, and upper Coniacian at both sites and in the upper Maestrichtian of Site 747. Site 748 (Fig. 4) contains a sequence of nannofossil-bearing glauconitic grainstones to wackestones that spans the Campanian and Maestrichtian. At least two disconformities (mid-Campanian and upper Maestrichtian) are evident. The graphic correlation of Sites 747 and 748 vs. Site 750 (Figs. 7 and 8) indicates that rates of rock accumulation at the inner to outer neritic depositional location of Site 748 was much higher than at pelagic Sites 747 and 750 .

A set of 21 biostratigraphic events (Fig. 2) was used to correlate the sections on Kerguelen. These consist of a mixture of purely austral and cosmopolitan events. This allows a high level of biostratigraphic resolution that is simple to correlate with established zonations developed in temperate areas. Correlation from the pelagic paleoenvironments of Sites 747 and 750 to the neritic paleoenvironment of Site 748 indicates that these biostratigraphic events can be used in both nearshore and offshore sections, at least in the upper Campanian through lower Maestrichtian.

Examination of the species composition and assemblage structure of the Kerguelen material and comparison with other Southern Ocean sites indicates that the weak provincialism of the Coniacian-Santonian gave way to the severe provincialism of the Maestrichtian during the mid-Campanian. This change seems to correspond to an ocean-wide disconformity, which either marks or masks the event(s) that changed the weak ecologic gradient of the Coniacian-Santonian to the ecologically decoupled system of the Maestrichtian.

\section{ACKNOWLEDGMENTS}

Financial support was graciously supplied to the author by the USSAC-JOI and the Department of Geology, University of Nebraska. I thank Theresa Dunn and Purtyasti Resiwati for their help in sample preparation. The manuscript benefited from critical reviews by Jason A. Crux, James J. Pospichal, and Sherwood W. Wise, Jr. My thanks to Sherwood W. Wise, Jr., for his comments on problems related to Marthasterites furcatus, Repagalum parvidentatum, and Salvelinus fontinalis.

\section{SYSTEMATIC PALEONTOLOGY}

Family ZYGODISCACEAE Hay and Mohler (1967) Genus ZEUGRHABDOTUS Reinhardt (1965)

Zeugrhabdotus kerguelenensis Watkins, n.sp. (Plates 1 and 2)

Diagnosis. A large species of Zeugrhabdotus bearing a broad, short, cylindrical to conical stem composed of vertical prisms with terminations that form a linear pattern spiralling distally upward and inward. The stem fills the entire central area in distal view and is supported by a simple bridge running parallel to the minor axis.

Description. The rim is composed of $40-45$ zeugoid lathlike elements that are strongly imbricated laterally (on the outer face of the rim) and distally. The broad, low rim flares moderately in the dista direction. In proximal view, two depressions corresponding to the bridge lie along the minor axis. A thin plate or grid covers the proximal face. The stem fills the central area distally. The stem is composed of a series of discoid rhombohedra (rhombic laths) arranged in a sinistral spiral about an axis defined by the vertical center of the stem. Each lath overlaps its lower neighbor and is offset from it by $15^{\circ}$ Laths in adjacent spiral rows lie on top of each other, forming a set of what appear to be vertical prisms. Lath length decreases distally, resulting in a conical stem, which is often topped by a rosette of four to five rhombic laths.

Remarks. As viewed under the light microscope, specimens are generally found lying on their sides (lateral view; Plate 1, Figs. 8-10). In this orientation, they resemble Zeugrhabdotus embergerii in a similar orientation, although the nature of the stem separates the two forms. Zeugrhabdotus pseudanthophorus (= Upper Cretaceous Zeugrhabdotus or Parhabdolithus embergerii of some workers) is similar to $Z$. kerguelenensis in size and rim shape but differs in the relative size and shape of the stem. Zeugrhabdotus kerguelenensis is easily distinguished from other zygodiscaceans by its large size and the nature of its stem.

The nature of the proximal face is uncertain because the Kerguelen specimens examined are imperfectly preserved. SEM examination of the Kerguelen specimens suggests the presence of a plate or grid composed of radial elements. This is best illustrated in the first paratype (Plate 1, Fig. 4) where 5-6 thin laths on the right side of the proximal face appear to radiate toward the center of the proximal face.

The surface of the elements composing the rim have been etched in the Kerguelen specimens, revealing sets of parallel lines or lineaments of small rugae (Plate 1, Figs. 2 and 5; Plate 2, Fig. 1). Each line is separated from adjacent ones by linear depressions or areas lacking rugae (Plate 1, Fig. 6). The distance between adjacent lines is approximately $0.1 \mu \mathrm{m}$. The line sets run circumferentially about the rim and are obliquely truncated at the element edge (Plate 1, Fig. 5). This pattern of line sets is interpreted to indicate that the individual rim elements are composed of $20-30$ stacked prisms or needles of calcite approximately $0.1 \mu \mathrm{m}$ in height.

Occurrence. upper Santonian-lower Campanian.

Size. rim length 8-11 $\mu \mathrm{m}$; rim width 4-7 $\mu \mathrm{m}$; stem height 4-6 Gmm.

Holotype. Plate 1, Fig. 1. UNSM

Holotype specimen. Plate 1, Figs. 1-3. UNSM

Paratypes. Plate 1, Figs. 4-6; Plate 2.

Type locality. ODP Sample 120-747C-10R-1, (147-148 cm); upper Santonian of the Kerguelen Plateau.

Additional occurrence. ODP Sample 114-700B-54R-3, 13-14 cm; upper Santonian of the Northeast Georgia Rise, South Atlantic Ocean (J. A. Crux, pers. comm., 1990).

Holotype and paratypes are deposited in the permanent collections of the University of Nebraska State Museum (UNSM), Lincoln, Nebraska, U.S.A.

\section{REFERENCES}

Bukry, D., 1973. Coccolith and silicoflagellate stratigraphy, Tasman Sea and southwestern Pacific Ocean, Deep Sea Drilling Project, Leg 21. In Burns, R. E., Andrews, J. E., et al., Init. Repts. DSDP, 21: Washington (U.S. Govt. Printing Office), 885-893.

Crux, J. A., 1990. Calcareous nannofossils recovered by Leg 114 in the subantarctic South Atlantic Ocean. In Ciesielski, P. F., Kristoffersen, Y., et al., Proc. ODP, Sci. Results, 114: College Station, TX (Ocean Drilling Program), 155-177.

Loeblich, A. R., and Tappan, H., 1966. Annotated index and bibliography of the calcareous nannoplankton. Phycologia, 5:81-215. 1968. Annotated index and bibliography of the calcareous nannoplankton II. J. Paleontol., 42:584-598.

1969. Annotated index and bibliography of the calcareous nannoplankton III. J. Paleontol., 43:568-588.

1970a. Annotated index and bibliography of the calcareous nannoplankton IV. J. Paleontol., 44:558-574.

1970b. Annotated index and bibliography of the calcareous nannoplankton V. Phycologia, 9:157-174.

1971. Annotated index and bibliography of the calcareous nannoplankton VI. Phycologia, 10:315-339.

1973. Annotated index and bibliography of the calcareous nannoplankton VII. J. Paleontol., 47:715-759. 
Perch-Nielsen, K., 1979a. Calcareous nannofossil zonation at the Cretaceous/Tertiary boundary in Denmark. In Birkelund, T., and Bromley, R. G. (Eds.), Cretaceous/Tertiary Boundary Events (Vol. 1). Copenhagen (Univ. of Copenhagen), 115-135. 1979 b. Calcareous nannofossils from the Cretaceous between the North Sea and the Mediterranean. In Wiedmann, J. (Ed.), Aspekte der Kreide Europeas. Int. Union Geol. Sci., Ser. A, $6: 223-272$.

1985. Mesozoic calcareous nannofossils. In Bolli, H., Saunders, J. B., and Perch-Nielsen, K. (Eds.), Plankton Stratigraphy: Cambridge (Cambridge Univ. Press), 329-426.

Pospichal, J. J., 1989. Southern high latitude K/T boundary calcareous nannofossils from ODP Sites 690 and 752. INA Newsl., 11:90-91.

Pospichal, J. J., and Wise, S. W., Jr., 1990. Maestrichtian calcareous nannofossil biostratigraphy of Maud Rise, ODP Leg 113 Sites 689 and 690, Weddell Sea. In Barker, P. R., Kennett, J. P., et al., Proc. ODP, Sci. Results, 113: College Station TX (Ocean Drilling Program), 465-487.

Schlich, R., Wise, S. W., Jr., et al., 1989. Proc. ODP, Init Repts., 120: College Station, TX (Ocean Drilling Program).

Sissingh, W., 1977. Biostratigraphy of Cretaceous calcareous nannoplankton. Geol. Mijnbouw, 56:37-65.

Steinmetz, J. C., 1984a. Bibliography and taxa of calcareous nannoplankton - III. INA Newsl., 6:6-37.

1984b. Bibliography and taxa of calcareous nannoplankton - IV. INA Newsl., 6:55-81. 1985a. Bibliography and taxa of calcareous nannoplankton - V INA Newsl., 7:5-28. 1985b. Bibliography and taxa of calcareous nannoplankton - VI. INA Newl., 7:122-145. 1986. Bibliography and taxa of calcareous nannoplankton - VIII. INA Newsl., 8:66-87. 1987a. Bibliography and taxa of calcareous nannoplankton-IX. INA Newsl., 9:6-29. 1987b. Bibliography and taxa of calcareous nannoplankton - X. INA Newsl., 10:81-109.

1988a. Bibliography and taxa of calcareous nannoplankton-XI. INA Newsl., 10:7-28.

1988b. Bibliography and taxa of calcareous nannoplankton XII. INA Newsl., 10:60-88.

1989. Bibliography and taxa of calcareous nannoplankton-XIII. INA Newsl., 11:6-23.

Thierstein, H. R., 1974. Calcareous nannoplankton-Leg 26, Deep Sea Drilling Project. In Davies, T. A., Luyendyk, B. P., et al., Init. Repts. DSDP, 26: Washington (U.S. Govt. Printing Office), 619667.

1976. Mesozoic calcareous nannoplankton biostratigraphy of marine sediments. Mar. Micropaleontol., 1:325-362.

1981. Late Cretaceous nannoplankton and the change at the Cretaceous/Tertiary boundary. In Warme, J. E., Douglas, R. G., and Winterer, E. L. (Eds.), The Deep Sea Drilling Project: A Decade of Progress: Spec. Publ. Soc. Econ. Paleontol. Mineral., 32:355-394.

van Heck, S. E., 1979a. Bibliography and taxa of calcareous nannoplankton. INA Newsl., 1:AB1-B27.

1979b. Bibliography and taxa of calcareous nannoplankton.

INA Newsl., 1:ABV1-B42.

1980a. Bibliography and taxa of calcareous nannoplankton.

INA Newsl., 2:5-34.

1980b. Bibliography and taxa of calcareous nannoplankton.

INA Newsl., 2:43-81.

1981a. Bibliography and taxa of calcareous nannoplankton. INA Newsl., 3:4-41.

1981b. Bibliography and taxa of calcareous nannoplankton. INA Newsl., 3:51-86.

1982a. Bibliography and taxa of calcareous nannoplankton.

INA Newsl., 4:7-50.

1982b. Bibliography and taxa of calcareous nannoplankton.

INA Newsl., 4:65-96.

1983. Bibliography and taxa of calcareous nannoplankton.

INA Newsl., 5:4-13.
Watkins, D. K, Wise, S. W., Jr., and Pospichal, J, J., 1989. Turonian-Maastrichtian nannofossil biostratigraphy and paleoceanography of the Southern Ocean. INA Newsl., 11:106.

Wind, F. H., 1979a. Late Campanian and Maestrichtian calcareous nannoplankton biogeography and high-latitude biostratigraphy [Ph.D. dissert.]. Florida State Univ., Tallahassee.

1979b. Maestrichtian-Campanian nannofloral provinces of the southern Atlantic and Indian Oceans. In Talwani, M., Hay, W., and Ryan, W.B.F. (Eds.), Deep Sea Drilling Results in the Atlantic Ocean: Continental Margins and Paleoenvironment: Am. Geophys. Union, Maurice Ewing Ser., 3:123-137.

Wind, F. H., and Wise, S. W., Jr., 1983. Correlation of Upper Campanian-Lower Maestrichtian calcareous nannofossil assemblages in drill and lower piston cores from the Falkland Plateau, Southwest Atlantic Ocean. In Ludwig, W. J., Krasheninnikov, V. A., et al., Init. Repts. DSDP, 71: Washington (U.S. Govt. Printing Office), 551-563.

Wise, S. W., Jr., 1983. Mesozoic and Cenozoic calcareous nannofossils recovered by Deep Sea Drilling Project Leg 71 in the Falkland Plateau region, Southwest Atlantic Ocean. In Ludwig, W. J., Krasheninnikov, V. A., et al., Init. Repts. DSDP, 71: Washington (U.S. Govt. Printing Office), 481-550.

1988. Mesozoic-Cenozoic history of calcareous nannofossils in the region of the Southern Ocean. Palaeogeogr., Palaeoclimatol., Palaeoecol., 67:157-179.

Wise, S. W., Jr., and Wind, F. H., 1977. Mesozoic and Cenozoic calcareous nannofossils recovered by DSDP Leg 36 drilling on the Falkland Plateau, Southwest Atlantic sector of the Southern Ocean. In Barker, P., Dalziel, I.W.D., et al., Init. Repts. DSDP, 36: Washington (U.S. Govt. Printing Office), 269-492.

Worsley, T. R., and Martini, E., 1970. Late Maestrichtian nannoplankton provinces. Nature, 225:1242-1243.

Date of initial receipt: 15 February 1990

Date of acceptance: 5 October 1990

Ms 120B-180

\section{APPENDIX}

\section{Mesozoic Nannofossils Considered in this Report} In Alphabetical Order of Generic Epithets

Acuturris scotus (Risatti, 1973) Wind and Wise in Wise and Wind, 1977 A hmuellerella octoradiata (Gorka, 1957) Reinhardt (1964)

Arkhangelskiella cymbiformis Vekshina (1959)

Arkhangelskiella specillata Vekshina (1959)

Aspidolithus parcus constrictus (Hattner et al., 1980) Perch-Nielsen (1984)

Aspidolithus parcus expansus (Wise and Watkins in Wise, 1983) Perch-Nielsen (1984)

Aspidolithus parcus parcus (Stradner, 1963) Noël (1969)

Biantholithus sparsus Bramlette and Martini (1964)

Bidiscus rotatorius Bukry (1969)

Biscutum constans (Gorka, 1957) Black in Black and Barnes (1959)

Biscutum coronum Wind and Wise in Wise and Wind (1977)

Biscutum dissimilis Wind and Wise in Wise and Wind (1977)

Biscutum magnum Wind and Wise in Wise and Wind (1977)

Biscutum notaculum Wind and Wise in Wise and Wind (1977)

Braarudosphaera bigelowii (Gran and Braarud, 1935) Deflandre (1947)

Broinsonia dentata Bukry (1969)

Broinsonia enormis (Shumenko, 1968) Manivit (1971)

Calculites obscurus (Deflandre, 1959) Prins and Sissingh in Sissingh (1977)

Ceratolithoides aculeus (Stradner, 1961) Prins and Sissingh in Sissingh (1977)

Chiastozygus garrisonii Bukry (1969)

Chiastozygus litterarius (Gorka, 1957) Manivit (1971)

Cretarhabdus conicus Bramlette and Martini (1964)

Cretarhabdus loriei Gartner (1968)

Cretarhabdus surirellus (Deflandre in Deflandre and Fert, 1954) Reinhardt (1970)

Cribrosphaerella daniae Perch-Nielsen (1973) 
Cribrosphaerella ehrenbergii (Arkhangelsky, 1912) Deflandre in Piveteau (1952)

Cyclagelosphaera margerelii Noël (1965)

Eiffellithus eximius (Stover, 1966) Perch-Nielsen (1968)

Eiffellithus gorkae Reinhardt (1965)

Eiffellithus turriseiffeli (Deflandre in Deflandre and Fert, 1954) Reinhardt (1965)

Eprolithus floralis (Stradner, 1962) Stover (1966)

Gartnerago obliquum (Stradner, 1963) Noël (1970)

Gartnerago segmentatum (Stover, 1966) Thierstein (1974)

Gephyrobiscutum diabolum Wise (1988)

Gephyrorhabdus coronadventis (Reinhardt, 1966) Hill (1976)

Glaukolithus compactus (Bukry, 1969) Perch-Nielsen (1984)

Helicolithus trabeculatus (Gorka, 1957) Verbeek (1977)

Kamptnerius magnificus Deflandre (1959)

Lapideacassis glans Black (1971)

Lapideacassis mariae Black (1971) emend. Wind and Wise in Wise and Wind (1977)

Lapideacassis tricornus Wind and Wise in Wise and Wind (1977)

Lithastrinus grillii Stradner (1962)

Lithastrinus moratus Stover (1966)

Lithastrinus septenarius Forchheimer (1972)

Lithraphidites carniolensis Deflandre (1963)

Lithraphidites quadratus Bramlette and Martini (1964)

Lucianorhabdus arcuatus Forchheimer (1972)

Lucianorhabdus cayeuxii Deflandre (1959)

Lucianorhabdus maleformis Reinhardt (1966)

Manivitella pemmatoidea (Deflandre in Manivit, 1965) Thierstein (1971)

Markalius inversus (Deflandre in Deflandre and Fert, 1954) Bramlette and Martini (1964)

Marthasterites furcatus (Deflandre in Deflandre and Fert, 1954) Deflandre (1959)

Microrhabdulus belgicus Hay and Towe (1963)

Microrhabdulus decoratus Deflandre (1959)

Micula concava (Stradner in Martini and Stradner, 1960) Verbeek (1976)

Micula decussata Vekshina (1959)

Micula murus (Martini, 1961) Bukry (1973)

Misceomarginatus pleniporus Wind and Wise in Wise and Wind (1977)

Monomarginatus pectinatus Wind and Wise in Wise and Wind (1977)

Monomarginatus quaternarius Wind and Wise in Wise and Wind (1977)

Neocrepidolithus watkinsii Pospichal and Wise (1990)

Nephrolithus corystus Wind (1983)

Nephrolithus frequens frequens Gorka (1957)

Nephrolithus frequens miniporus (Reinhardt and Gorka, 1967 ) Pospichal and Wise (1990)
Octolithus multiplus (Perch-Nielsen, 1973) Romein (1979)

Placozygus fibuliformis (Reinhardt, 1964) Hoffmann (1970)

Placozygus sigmoides (Bramlette and Sullivan, 1961) Romein (1979)

Prediscosphaera bukryi Perch-Nielsen (1973)

Prediscosphaera cretacea (Arkhangelsky, 1912) Gartner (1968)

Prediscosphaera grandis Perch-Nielsen (1979)

Prediscosphaera intercisa (Deflandre in Deflandre and Fert, 1954) Shumenko (1976)

Prediscosphaera ponticula (Bukry, 1969) Perch-Nielsen (1984)

Prediscosphaera spinosa (Bramlette and Martini, 1964) Gartner (1968)

Prediscosphaera stoveri (Perch-Nielsen, 1968) Shafik and Stradner (1971)

Quadrum gartneri Prins and Perch-Nielsen in Manivit et al. (1977)

Quadrum gothicum (Deflandre, 1959) Prins and Perch-Nielsen in Manivit et al. (1977)

Quadrum sissinghii Perch-Nielsen (1984)

Quadrum trifidum Stradner in Stradner and Papp, 1961) Prins and Perch-Nielsen in Manivit et al. (1977)

Reinhardtites anthophorus (Deflandre, 1959) Perch-Nielsen (1968)

Reinhardtites levis Prins and Sissingh in Sissingh (1977)

Repagalum parvidentatum (Deflandre in Deflandre and Fert, 1954) Forchheimer (1972)

Rhagodiscus angustus (Stradner, 1963) Reinhardt (1971)

Rhagodiscus splendens (Deflandre, 1953) Verbeek (1977)

Rhombolithion rhombicum (Stradner and Adamiker, 1966) Black (1973)

Scampanella magnifica Perch-Nielsen in Perch-Nielsen and Franz (1977)

Seribiscutum primitivum (Thierstein, 1974) Filewicz et al. in Wise and Wind (1977)

Sollasites lowei (Bukry, 1969) Roth (1970)

Stoverius asymmetricus (Bukry, 1969) Perch-Nielsen (1984)

Stradneria crenulata (Bramlette and Martini, 1964) Noël (1970)

Teichorhabdus ethmos Wind and Wise in Wise and Wind (1977)

Thiersteinia ecclesiastica Wise and Watkins in Wise (1983)

Tranolithus phacelosus Stover (1966)

Vekshinella angusta (Stover, 1966) Verbeek (1977)

Vekshinella dibrachiata Gartner (1968)

Vekshinella parma Wind and Wise in Wise and Wind (1977)

Vekshinella stradneri Rood et al. (1971)

Watznaueria barnesae (Black in Black and Barnes, 1959) PerchNielsen (1968)

Watznaueria supracretacea (Reinhardt, 1965) Wind and Wise in Wise and Wind (1977)

Zeugrhabdotus elegans Gartner (1968)

Zeugrhabdotus pseudanthophorus (Bramlette and Martini, 1964) Perch-Nielsen (1984) 

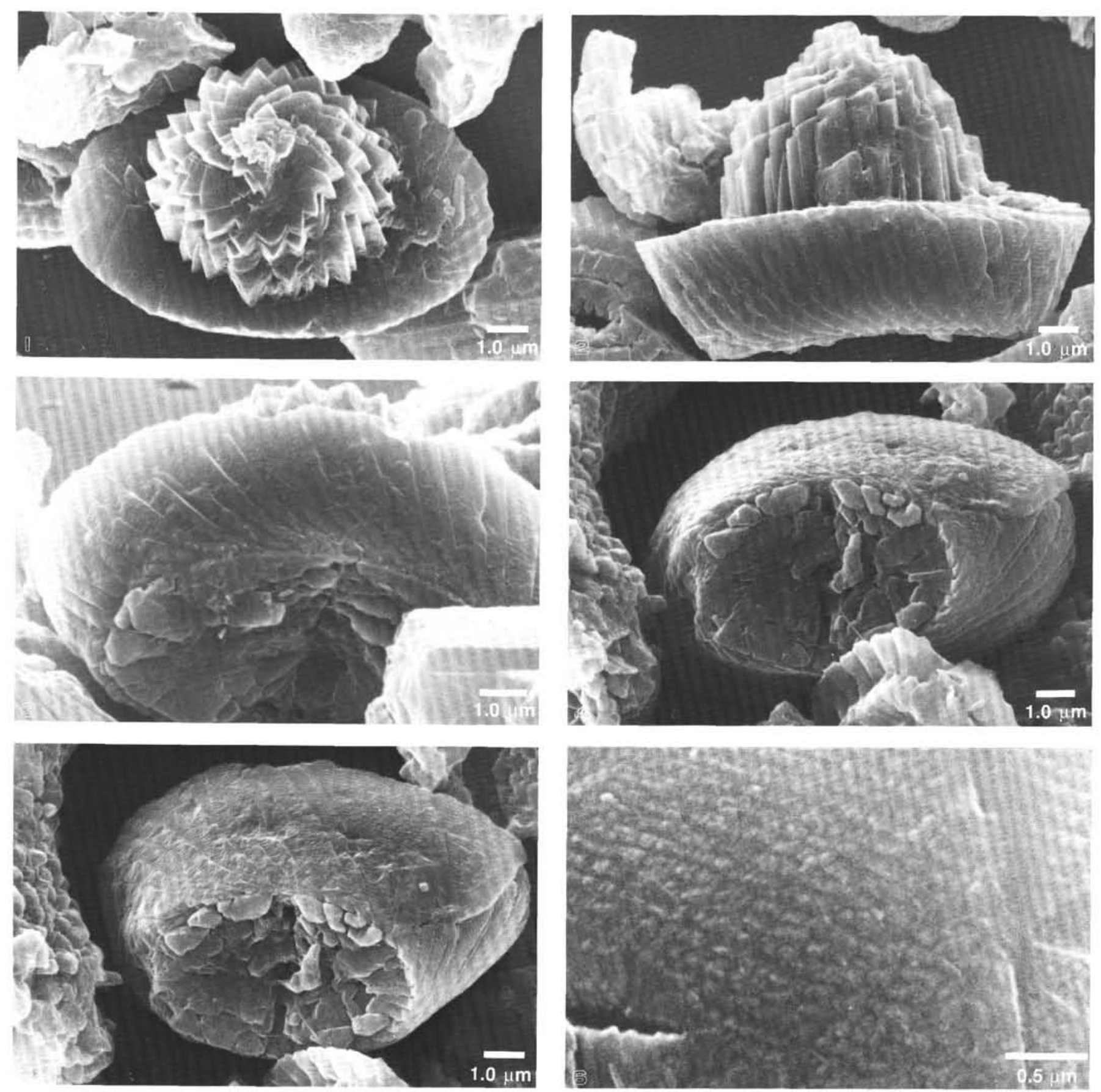

Plate 1. Zeugrhabdotus kerguelenensis n.sp. 1-3. Holotype specimen (Sample 120-747C-10R-1, 40-41 cm); (1) distal view (holotype), (2) lateral view, (3) oblique proximal view. 4-6. Paratype specimen (sample as above); (4) proximal view illustrating depressions on minor axis corresponding to bridge and indications of radial grid or plate made of radial elements at right-hand side of proximal face; (5) oblique lateral view showing pronounced lineaments enhanced by etching; (6) close-up of Figure 5 showing character of lineaments on etched element surface. 

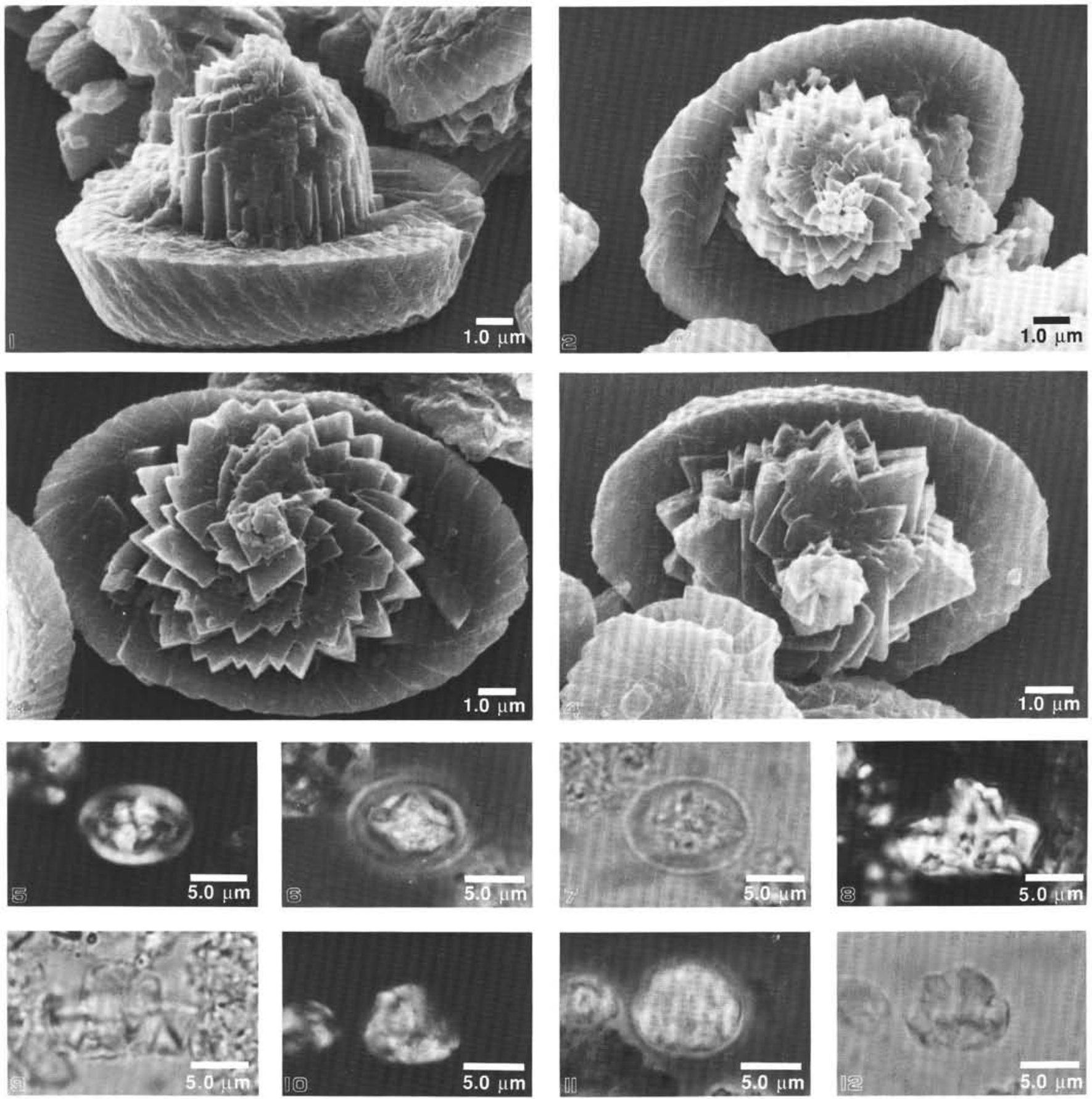

Plate 2. Zeugrhabdotus kerguelenensis n.sp. Paratype specimens (Sample 120-747C-10R-1, 40-41 cm). 1. Lateral view-note spiral "staircases" formed by lath-size reduction at distal end of stem and pattern of circumferential lines in rim elements. 2. Distal view of specimen in Figure 1 illustrating stem with distinctive rosette at tip. 3. Distal view showing stem construction. 4. Distal view of etched specimen exhibiting overgrown terminal rosette. 5-7. Distal view, light microscope; (5) cross-polarized light (Pol), (6) transmitted light (Tr), (7) phase-contrast light (Ph). 8-9. Lateral view along major axis; (8) Pol, (9) Tr. 10-12. Oblique lateral view, light microscope; (10) Pol, (11) Ph, (12) Tr. 

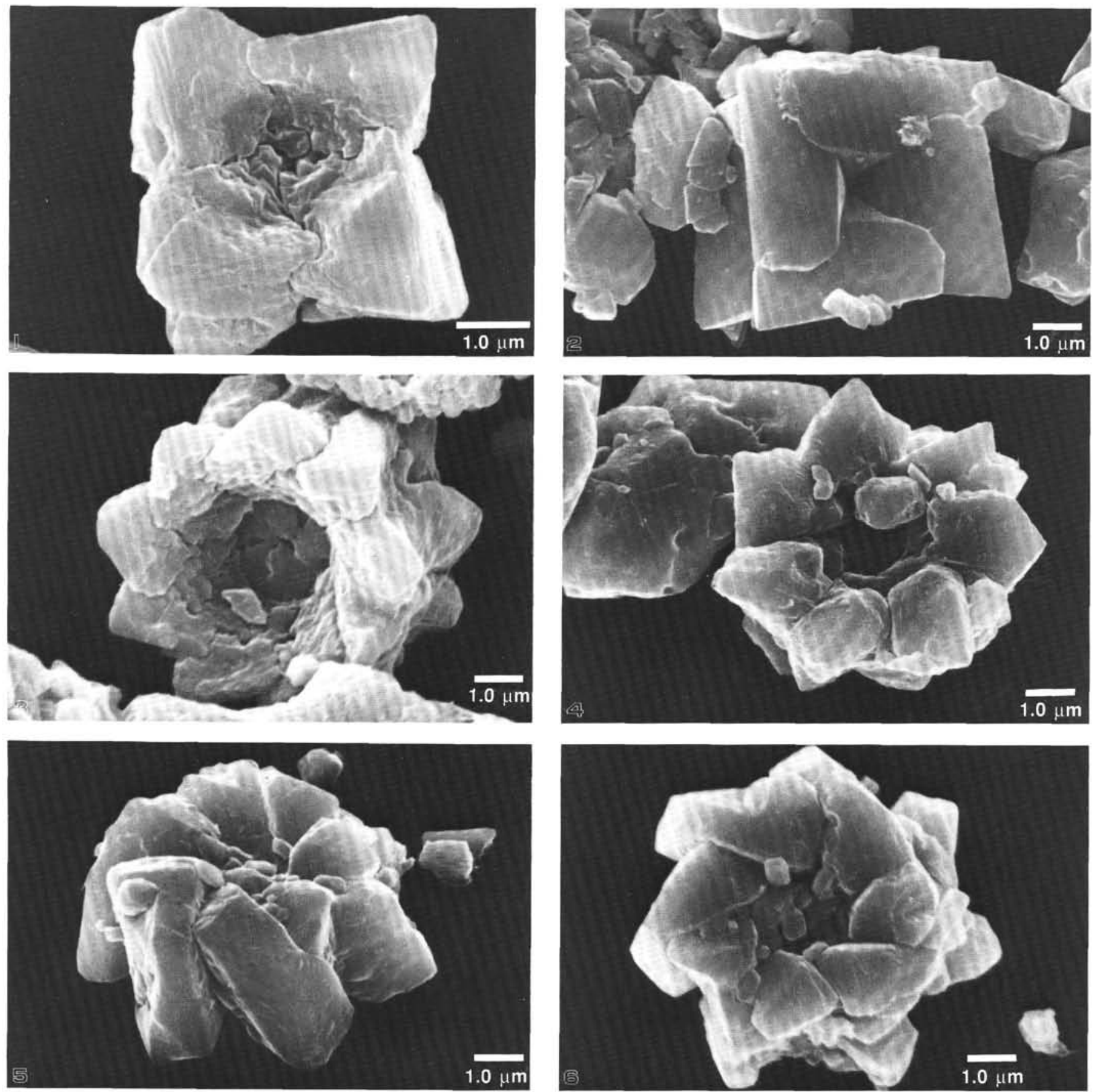

Plate 3. 1. Quadrum gartneri (Sample 120-747C-10R-1, 147-148 cm). 2. Micula decussata (Sample 120-750B-9W-1, 40-42 cm). 3. Eprolithus floralis (Sample 120-747C-10R-1, 147-148 cm). 4-6. Lithastrinus septenarius (Sample 120-747C-10R-1, 40-41 cm); (4) distal view, (5) oblique lateral view illustrating rotation of wall elements, (6) proximal view, same specimen as Figure 5. 

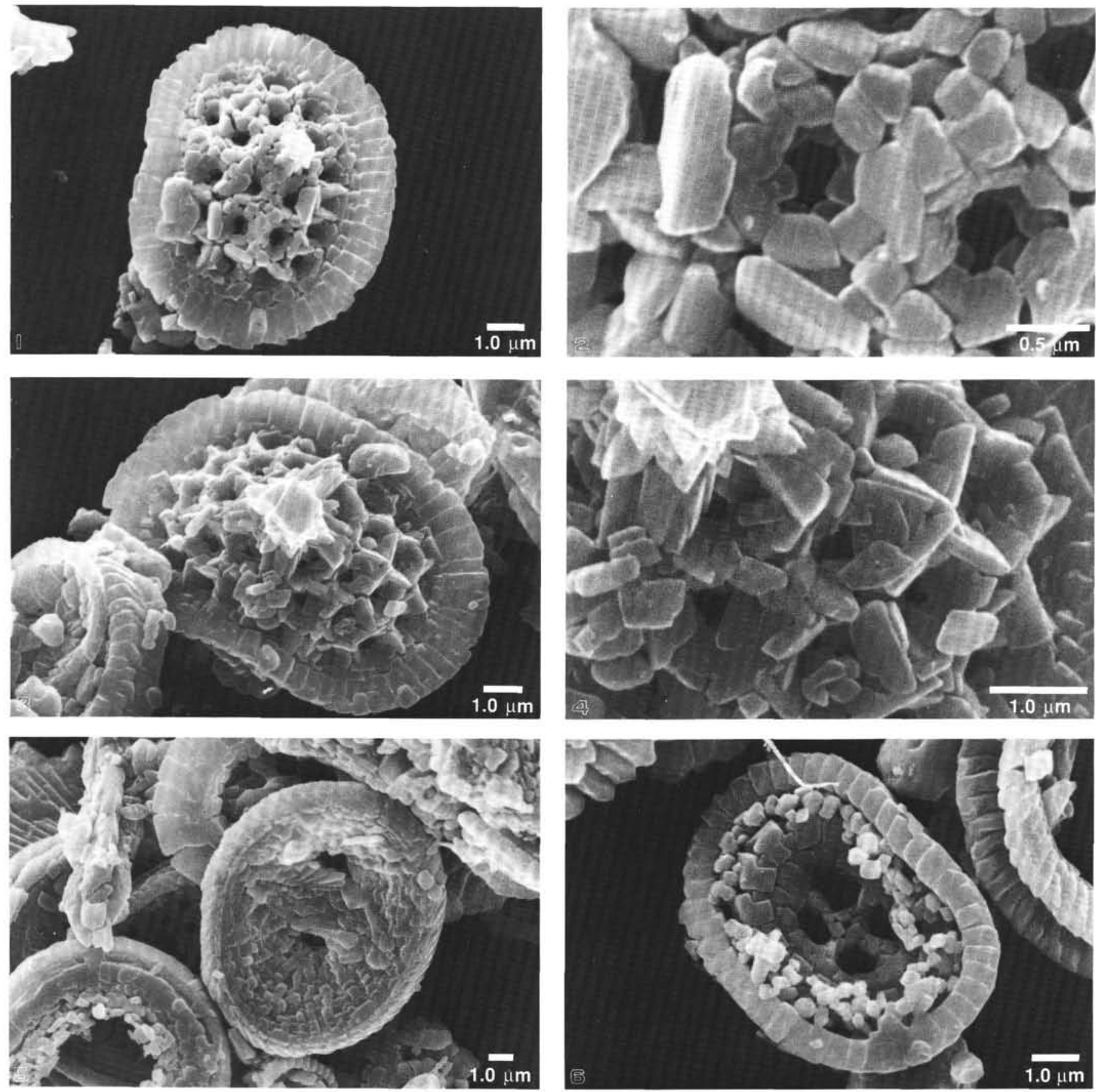

Plate 4. Sample 120-750A-20R-1, 40-41 cm. 1-2. Nephrolithus frequens; (1) distal view, (2) close-up of Figure 1 illustrating diagnostic ring of elements on central area pores. 3-4. Nephrolithus corystus; (3) distal view, (4) Close-up of Figure 3 showing pore detail. 5. Reinhardtites levis, distal view, same sample as above 6 . Nephrolithus sp. cf. $N$. corystus, aberrant(?) specimen exhibiting uncharacteristically well-developed cross and pore arrangement as stem support. 

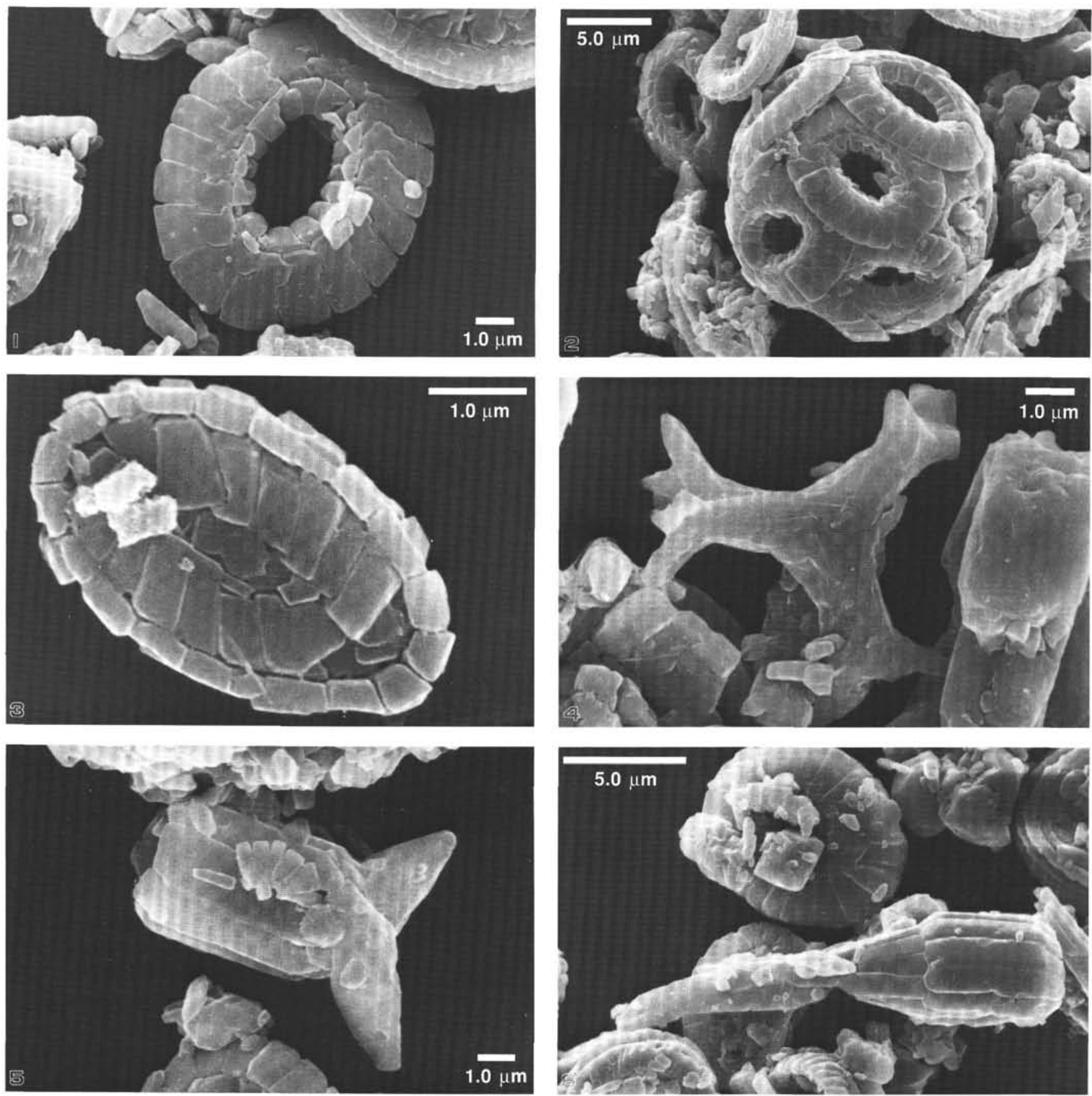

Plate 5. 1. Biscutum magnum (Sample 120-750A-20R-1, 40-41 cm). 2. Coccosphere of B. magnum, same sample as Figure 1. 3. Species A (Sample 120-750B-9W-1, 40-42 cm) 4. Marthasterites furcatus (Sample 120-747C-10R-1, 147-148 cm). 5. Lapideacassis tricornus (Sample 120-750A-20R-1, 40-41 cm). 6. Scampanella magnifica (Sample 120-750A-20R-1, 40-41 cm). 